Rhode Island College

Digital Commons @ RIC

$12-12-2018$

\title{
The Influence of Depression on Pain in the Postoperative Setting: A Systematic Review
}

Lewis Lateef Olaoluwa

Follow this and additional works at: https://digitalcommons.ric.edu/etd

Part of the Perioperative, Operating Room and Surgical Nursing Commons

\section{Recommended Citation}

Olaoluwa, Lewis Lateef, "The Influence of Depression on Pain in the Postoperative Setting: A Systematic Review" (2018). Master's Theses, Dissertations, Graduate Research and Major Papers Overview. 282.

https://digitalcommons.ric.edu/etd/282

This Major Paper is brought to you for free and open access by the Master's Theses, Dissertations, Graduate Research and Major Papers at Digital Commons @ RIC. It has been accepted for inclusion in Master's Theses, Dissertations, Graduate Research and Major Papers Overview by an authorized administrator of Digital Commons @ RIC. For more information, please contact digitalcommons@ric.edu. 
THE INFLUENCE OF DEPRESSION ON PAIN IN THE

POSTOPERATIVE SETTING:

A SYSTEMATIC REVIEW

A Major Paper Presented

by

Lewis Lateef Olaoluwa

Approved:

Committee Chairperson

Committee Members

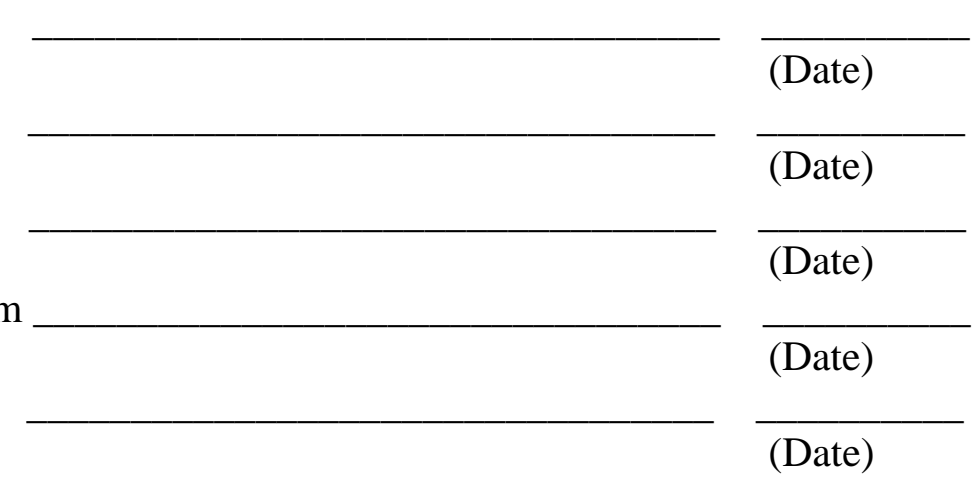


THE INFLUENCE OF DEPRESSION ON PAIN IN THE POSTOPERATIVE SETTING:

\section{A SYSTEMATIC REVIEW}

by

Lewis Lateef Olaoluwa

A Major Paper Submitted in Partial Fulfillment

of the Requirements for the Degree of

Master of Science in Nursing

in

The School of Nursing

Rhode Island College

2018 


\begin{abstract}
Over 5\% of Americans over the age of 12 reported depression between 20052006, and it remains the second leading cause of death in the adolescent and the early adulthood population. The estimated worldwide impact of depression affects approximately 300 million people (World Health Organization [WHO], 2017). Few research studies analyzed the correlation of depression and postoperative pain. The impact of depression on physiological wellbeing, and evidence from various studies suggest a correlation between psychological illnesses such as depression and the physiological manifestations of pain. This systematic review will consider Randomized Controlled Trials (RCT’s), however in the absence of RCT’s, a Quasi-experimental design, and Prospective cohort studies, will be included. Inclusion criteria for the systematic review consists of: adults $\geq 18$ years of age with self-reported depression, subjects who have mild, moderate, or severe postoperative pain, subjects who received anesthesia or analgesia, and who underwent ambulatory surgery. Six of the nine studies reported higher postoperative pain levels among participants who had increased preoperative depression, and three out nine studies reported a negative correlation. Overall limitations in this review include the inability to obtain the highest level of evidence such as RCT’s. Due to lack of available RCT studies, cohort studies provided the primary basis of information for which this study relied. Cohort studies do not provide the highest level of evidence, and therefore an increased level of heterogenicity within this study was apparent.
\end{abstract}




\section{Acknowledgements}

I would like to acknowledge my wonderful friends and family who gave me the strength and motivation to follow my dreams and achieve my highest goals. Your unselfishness and dedication to my cause has allowed me to get through one of the toughest obstacles before me. Your efforts have not gone in vain, and your selfless love will forever resonate with me as I embark on a life-long journey, which I will never forget began with you. 


\section{Table of Contents}

Background/Statement of the Problem ................................................................. 1

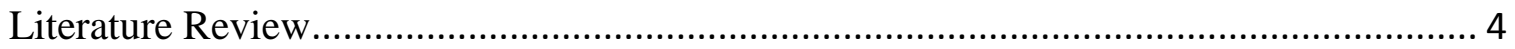

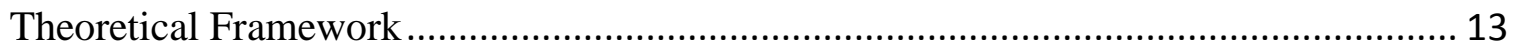

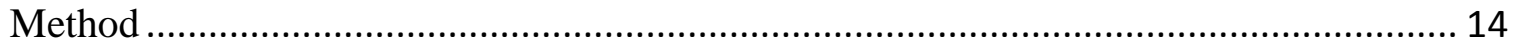

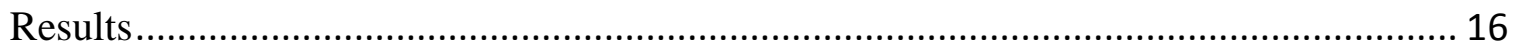

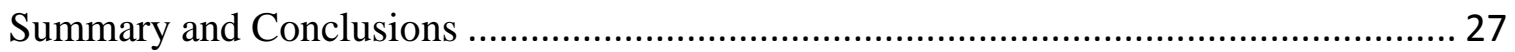

Recommendations and Implications for Advanced Nursing Practice ........................... 30

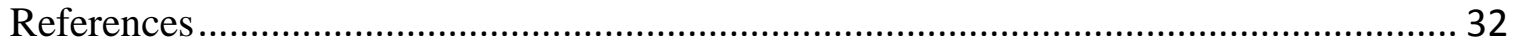

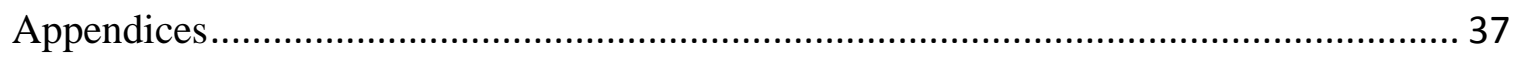




\section{Background/Statement of the Problem}

Over 5\% of Americans over the age of 12 reported depression between 2005-2006, and it remains the second leading cause of death in the adolescent and the early adulthood population. The estimated worldwide impact of depression affects approximately 300 million people (World Health Organization [WHO], 2017). Depression is a common mental health disorder, characterized by sadness, loss of interest or pleasure, feelings of guilt or low self-worth, disturbed sleep or appetite, feelings of tiredness, and poor concentration (Pratt \& Body, 2008).

Although depression is a psychological disorder, interrelationships between depression and physical health are evident, and may manifest as commonly unrecognizable signs and symptoms. Cyranowiski, Hofkens, Swartz, and Gianaros, (2011) studied the impact of non-depressed versus depressed women on blood pressure, heart rate, and tension. The participants' psychological stress were tested by the use of imagery, and a stressful task. An increase in the aforementioned measures demonstrated a negative impact on physiological stress. Other accepted physiological changes include muscle aches, sleep disturbances, decreased appetite, back pain, headaches, and fatigue (WHO, 2017).

References cited within this literature review describe the impact of depression on physiological wellbeing, and evidence from various studies suggest a correlation between psychological illnesses such as depression and the physiological manifestations of pain. Further review of this relationship may be clinically significant and may help guide clinicians in the understanding of how these variables influence one another. 
This inquiry may support clinicians in optimizing treatment for patients who undergo surgical procedures likely to induce pain, who also present with underlying depression. If clinical depression is implicated as a variable which negatively influences a patient's perception of pain, or which serves as a barrier to pain relief, poor clinical outcomes may result. According to the Institute of Medicine (2011), pain is a significant public health problem which costs society at least $\$ 560-\$ 635$ billion annually, an amount equal to about $\$ 2,000.00$ for everyone living in the United States. Furthermore, the American Pain Foundation (2006) found more than three quarters of patients (77\%) reported feeling depressed along with their symptoms of pain.

Understanding the barriers to postoperative pain management, with an emphasis on depression as a variable co-morbidity, may challenge conventional therapeutic modalities currently in use. An overwhelming amount of research has been conducted on pain, its causes, effects, how it is measured, the physiology, and therapeutic management. Existing literature supported by the scientific community suggests a strong correlation between chronic pain and the consequential development of depression (Surah, Baranidharan, \& Morley, 2014). However, less information is known on the influence of preexisting depression and the experience of pain after a surgical procedure. This phenomenon requires further review of the literature, as it may be clinically relevant, thus warranting a change in perspective on pain and how clinicians address pain management in this patient population.

Moreover, clinicians such as anesthesia providers are important stakeholders in the conversation of pain, and responsible for managing pain in the pre, intra, and postoperative phases of a surgical procedure. As a standard of care in anesthesia, a psychiatric history is 
included as a part of a head-to-toe systems review prior to a surgical procedure. In addition to a psychiatric history, an inquiry of medications is completed to determine medications that must be stopped or continued prior to a procedure. This is an important aspect of a preoperative assessment. It provides information as to a patient's general health and underlying medication requirements. Many anesthetic agents aid in relieving anxiety and pain in the perioperative period, in addition to inducing a state of anterograde amnesia, muscle relaxation, and sedation. Although the effects of these anesthetic agents prove generally effective in the perioperative period, the effect may be short-lived, and the management of pain must remain on a continuum for pain refractory to analgesics. It is unknown if a client with known depression may need an individualized therapeutic regimen requiring a multimodal approach preoperatively and postoperatively, and possible adjustments in anti-depressive medications to mitigate unresolved postoperative pain. The proposed systematic review is to comparatively analyze data collected from studies of ambulatory surgical patients who have documented depression prior to a surgical procedure, and to further assess their pain levels and the duration of their pain experience postoperatively. 


\section{Literature Review}

Few research studies analyze the correlation of depression and postoperative pain. The following studies selected for review effectively isolate depression from other psychological conditions such as anxiety, catastrophizing, substance abuse, and other psychiatric alimental factors that have been shown in other various studies to influence postoperative pain. A review of the literature conducted by Ghoneim and O’Hara (2016) explored the link between pain and depression which explained that areas of the brain including the prefrontal cortex, ventral tegmental area, and hippocampus demonstrate altered synaptic connectivity and dopamine signaling. These alterations have been associated with the negative symptoms of depression and may form an interrelationship with pain.

The conducted review of the literature evaluated several studies which suggested a positive relationship between depression and postoperative mortality, morbidity, infection, progression of chronic illness, and higher pain scores. Although the analysis of Ghoneim and O’Hara (2016) suggest such findings, a majority of studies included in the literature overview demonstrate a lack of the highest level of evidence within research, by providing a limited number of randomized control trials (RCT's). The included studies are small, non-blinded, single center studies, and are subject to confounding variables. Further research conducted by Fishbain, Cutler, H. Rosomoff, and R. Rosomoff (1997) suggest several hypotheses including the scar, consequence, and antecedent hypothesis to explain the relationship between depression and pain. The scar hypothesis postulates that pain and illness predispose patients to depression and may exacerbate depressive episodes in patients with existing depression. The consequence hypothesis presented in the review also 
suggests depression precedes pain however, many researchers debate if the antecedent hypothesis is true, by which it postulates that depression is caused by pain.

Further studies conducted by Magni, Moreschi, Rigatti-Luchini, Merskey (1994) suggested depression and pain are interrelated due to imbalances of commonly shared neurochemicals such as catecholamine, serotonin, and endogenous opioids. The authors noted that the recent efficacy of tricyclic antidepressants in treating chronic pain is often cited as providing initial support for these imbalances.

The aforementioned studies by Fishbain et al. (1997) and Magni et al. (1994) established a relationship between depression and pain, however both studies were limited by small cross-sectional or retrospective studies. The use of self-reported questionnaires to correlate statistical relationships between pain and depression increased the likelihood of variability among the participants, therefore limiting the generalizability of the studies and increasing bias.

\section{Study Measurements in the Perioperative Setting}

Several studies reviewed utilize a variety of measurements to quantify pain and depression. Among the tools utilized to measure pain in general surgery patients include the Visual Analogue Scale (VAS), which is a scale that patients must visually indicate minimal or maximal pain on a continuum. The Numeric Rating Scale (NRS) is similar to the VAS, however the patient indicates a number from 0-10, 0 representing no pain, and 10 indicating maximal pain. Both scales are easy to obtain, reliable, valid and can detect changes over time (Lanitis et al., 2015). Within the same study, depression was measured using the Hospital Anxiety and Depression Scale (HADS), and this entails a physiological 
self-assessment consisting of fourteen items that measure anxiety and depression simultaneously. Each item is scored from 0-21, ranging from mild to moderate, and severe symptoms, and combined for a total score upon completion of the assessment.

Another study by Suffeda, Meissner, Rosendahl, and Guntinas-Lichius (2016) utilized the Quality Improvement in Postoperative Pain Treatment (QUIPS) instrument including NRS (0-10) for determination of the patient's maximal pain. QUIPS allowed standardized assessment of patients' characteristics, pain parameters, and outcomes. Moreover, the Patient Health Questionnaire (PHQ-9) is a 9-item checklist provided to participants to measure the severity of depression, and scores ranging from 0 to 27 , indicate the presence and severity of depression, with scores of 5, 10, 15, and 20 being the cutpoints for mild, moderate, moderately severe, and severe depression, respectively (Suffeda et al., 2016). The tool applied to measure surgery-related anxiety consisted of a 30-item inventory known as the State-Trait Operation Anxiety Inventory (STOA or STOI).

Additional measurements to assess depression and pain include: The MontgomeryAsberg Depression Rating Scale (MADRS) used by Caumo et al. (2002). The Brief-COPE, the Mental Health Inventory (MHI), the Impact of Events Scale (IES), the Negative Affect questionnaire (NA), the McGill Pain Questionnaire (MPQ or PRI-T), and the Morphine Consumption (MC) are measurements applied in the Cohen, Fouladi, and Katz (2005) research study. The Brief Pain Inventory (BPI), Screener and Opioid Assessment for Patients with Pain (SOAPP 24), Self-Perceived Susceptibility to Addiction, Beck Depression Inventory-II (BDI-II), Primary Care Posttraumatic Stress Disorder Screen, the Anxiety-Sensitivity Index, and The Fear of Pain Questionnaire are tools used in a prospective, longitudinal inception cohort study by Carroll et al. (2012). 
A prospective cohort study conducted by Chaichana, Mukherjee, Adogwa, Cheng, and, McGirt (2011) utilized measurements in the previously mentioned studies, however additional tools included in the study consisted of: The Quality of Life Health Survey (SF36), The Oswestry Disability Index, The Zung Self-Rating Depression Scale, and a Modified Somatic Perception Questionnaire (MSPQ) which appear to be proxy scales for depression. Lastly a retrospective cohort analysis conducted by Alvin et al. (2015) used a Pain Disability Questionnaire, and the EuroQol five dimensions questionnaire (EQ-5D). All measurements were tested as reliable in the studies mentioned. Several of the studies assessed depression and pain with the same measurement tools. The previously annotated measurements are included in this review to guide the reader in assessing the correlation and significance of studies contained in this review.

\section{General Surgery}

Research conducted by Lantitis et al. (2015) enrolled 400 patients in a prospective study which further divided patients into two groups, A and B. Group A were classified as participants without depression and consisted of 323 participants. Group B were classified as participants with depression, and this consisted of 63 participants. Both groups comparatively utilized quantifiable variables such as pre/postoperative pain using VAS, NRS, and other quantifiable variables i.e. (age, scar length, anxiety). Patients in group B generally were older, had longer scar lengths, higher anxiety scores, and increased preoperative and postoperative NRS and VAS scores. Qualitative measures conducted within the same study comparatively illustrates group B as having a higher female population. Moreover, participants in group B reported lower educational levels than group A, and demonstrate lower narcotic and analgesics use with decreased rates of smoking. 
Participants in group B also tended to have lower rates of previous surgeries and, of all the general surgery operations included in the study, group B received laparoscopic procedures at higher rates. In all other general surgery categories, group A experienced higher rates of abdominal, inguinal, breast/skin, and perianal surgeries.

Regarding the subgroup analysis based on the anxiety status, the authors reported that in the subgroup of patients without anxiety, those with depression experienced more preoperative pain (3.71 vs. $1.72, \mathrm{p}=0.047)$ and more pain during the 1 st PO day (4.62 vs. 3.22, $p=0.040$ ), while in the subgroup of patients with anxiety there were no differences in all the quantitative measures including pain. This is important because a significant predictor of pain, such as anxiety which is also closely linked to depression, was excluded as a confounding factor. The fact that in the subgroup of patients without anxiety the impact of depression was significant means that depression may be an independent predictor of pain (Lanitis et al., 2015).

Otolaryngologic Surgery. An observational study conducted by Suffeda et al. (2016) selected 82 participants to assess their preoperative psychological state by utilizing the PHQ-9, PCS, STOA, and resilience scale (RS-13). These measurement tools were comparatively analyzed against postoperative pain using both QUIPS and NRS. Characteristics of the preoperative psychological assessments included gender, education, American Society of Anesthesiologists (ASA) status, type of surgery, perioperative complications, and the preoperative psychological assessment tools. Most notably, the population in this study were represented by males (58.5\%), with less than a high school degree (68.3\%), ASA 3 status (57.3\%), scored 0 on the Charlson Comorbidity Index (61.0\%), endorsed to some level of depression (PHQ-9) (52.5\%), had high resilience (RS- 
13) $(79.3 \%)$, took no pain therapy prior to surgery (89.0\%), surgeries were of the middle ear (50.0\%), and participants did not experience perioperative complications (82.9\%). The results of the study as discussed by Suffeda et al. (2016) reported patients with higher depression scores (higher PHQ-9 depression score; P = 0.010; Fig. 2), higher STOA trait anxiety $(\mathrm{P}=0.044)$ and higher STOA sum scores $(\mathrm{P}=0.033)$ also reported higher levels pain. Suffeda et al. (2016) further disclosed that the comprehensive multivariate analysis of psychological factors at baseline, influenced parameters on maximal pain on the first postoperative day, revealing more depression (beta=0.256; 95\% CI: 0.042-0.404; p = 0.017), and the increased use of opioids in the recovery room (beta=0.371; 95\% CI: 0.1080.481; $\mathrm{p}=0.002$ ) were independent predictors for more maximal pain.

Abdominal Surgery. A prospective cohort study performed by Caumo at al., (2002) concluded that the univariate analysis revealed a significant association between acute postoperative pain and the following variables: age, ASA status, chronic pain, preoperative pain, surgery to treat cancer, epidural analgesia, trait anxiety, preoperative state-anxiety, and depression symptoms. In this study, postoperative pain was determined to be directly related to depression symptoms prior to the surgery. The univariate analysis of the study compared potential predicators of pain and acute postoperative pain. The VAS pain scale measurement tool was utilized to measure pain, and of the 346 participants who underwent abdominal surgery, 196 participants reported ‘absent or mild pain’, while 150 participants reported moderate or intense pain. The STAI and MADRS scales were measurement tools utilized in this study to assess participant's psychological state. Among the participants with absent or mild pain, 29 demonstrated a moderate to intense depressive mood, while 167 showed mild depressive moods. Moreover, of the participants with 
moderate to intense pain, 51 exhibited moderate to intense depressive moods, while 99 exhibited mild depressive moods.

Cervical \& Lumbar Surgery. Chaichana et al., (2011) conducted a prospective cohort study to determine the correlation of preoperative depression and quality of life after lumbar discectomy. Among the 76 participants included in the study, 10\% were clinically depressed, and followed over the course of one year. A multivariate logistic regression was used, and determined the least depressed patients, those in the lowest quartile of preoperative depression on the Zung Self-Rating Depression Scale scores had significantly greater improvement in all outcomes compared with the most depressed patients, those in the highest preoperative Zung Scale quartile, with regard to VAS-BP score, VAS-LP score, ODI score, and SF-36 PCS scores. Outcome measures were defined as a decrease in VAS or ODI score and an increase in SF-36 PCS score (Chaichana et al., 2011).

Furthermore, a similar correlation between preoperative depression and pain following cervical surgery can be corroborated by Alvin et al., (2015). This study measured pain outcomes using the Pain Disability Questionnaire (PDQ), and depression outcomes utilizing Patient Health Questionnaire-9 (PHQ-9). The findings of this retrospective cohort study determined that participants with severe preoperative depression demonstrated worse outcomes and quality of life after surgery, and analyses showed that increasing PHQ-9 and EuroQol 5-dimesnsions (EQ-5D) preoperative scores were associated with reduced 1-year postoperative improvement in health status (Alvin et al., 2015). 


\section{Postoperative Narcotic Consumption}

Further research by Cohen et al. (2005) and ÖZalp, Sarioglu, Tuncel, Aslan, and Kadiogullari (2003) suggested depression influences postoperative pain and is evident by evaluating the analgesic requirements of postoperative patients. ÖZalp et al. (2003) examined the relationship of preoperative depression and anxiety, and its relationship to PCA use in breast cancer. A multiple linear regression analysis utilizing STAI and BDI determined the pain intensity, total analgesic consumption, dose/demand ratio, and the degree of dissatisfaction with pain control were significantly related to preoperative anxiety and depression (ÖZalp et al., 2003). Overall, preoperative exposure measures influenced PCA opioid consumption as evidenced by postoperative outcomes within this study.

A similar randomized control trial by Cohen et al. (2005) utilized a multivariate regression analysis which included preoperative psychosocial measures such as MHI, IES, NA, Brief-COPE, and morphine consumption. Findings from Cohen et al. (2005) suggest, a negative affect 48 hours after surgery was associated with PRI-T scores 48 hours after surgery $(\mathrm{r}=.36$, P b.001). Similarly, negative affect 4 weeks after surgery was associated with PRI-T scores 4 weeks after surgery $(r=.46, \mathrm{P}$ b.001). Negative affect after surgery was not associated with postoperative morphine consumption $(\mathrm{r}=.14)$. However, postoperative pain levels were positively associated with morphine consumption $(\mathrm{r}=.32$, $\mathrm{P}$ $<.001)$ ". These findings suggest participants with preoperative psychological factors such as depression demonstrate increased pain scores after surgery, however this study did not show a positive correlation with morphine consumption. These findings contrast a prospective, longitudinal inception cohort study conducted by Carroll et al. (2012) which reported subjects with elevated levels of preoperative depressive symptoms were less likely 
to discontinue opioids after surgery, and were more likely to continue taking opioids 6 months after surgery.

Studies conducted by Caumo et al., 2002; Dadgostar, Bigder, Punjani, Lozo, Chahal, and Kavanagh, 2017; Kinjo, Sands, Lim, Paul, and, Leung, 2011; Lanitis et al., 2015; and Torres-Claramunt et al., 2017 suggest a positive correlation between depression and pain. As presented in the following systematic review, a diagnosis of depression or depressive symptoms were present prior to procedures. Depression often preceded the onset of pain symptoms, and studies demonstrated new onset of pain symptoms or increased pain perceptions in the postoperative period. The current literature review and systemic review to follow included studies that utilized different tools to measure depression and pain. However, most of the studies shared similar measurement tools. Studies including general surgery, otolaryngologic, abdominal, lumbar spine, and cervical spine surgeries yielded similar results. Studies that analyzed narcotic consumption among depressed patients demonstrated increased, prolonged narcotic use in the postoperative period. These studies established a relationship between the severity of self-reported depression symptoms and diminished postoperative pain relief with narcotics warranting further investigation. 


\section{Theoretical Framework}

A systematic review is a research study which is formally structured to identify, assess, and analyze studies in order to address an interrelated identical question (Institute of Medicine, 2011). A systematic review was conducted and guided using the Preferred Reporting Items for Systematic reviews and Meta-Analyses (PRISMA) as a theoretical framework. PRISMA is a revision of the Quality of Reporting of Meta-analyses (QUOROM) that was established in 1996 (Moher, Liberati, Tetzlaff, \& Altman, 2009). The goals of the PRISMA theoretical framework is to ensure improved reporting of systematic reviews, meta-analyses, thus producing enhanced transparency, and reducing the similarity of clinical questions amongst authors. The focus is predominately on randomized trials, but PRISMA can also be used as a basis for reporting systematic reviews of other types of research, particularly evaluations of interventions.

The PRISMA Statement consists of a 27-item checklist and a four-phase flow diagram (Moher et al., 2009). The 27-item checklist contains categories that introduce a topic/section in the left sided column, and adjacent to this, a numerically listed checklist of items that detail the requirements needed to fulfill a systematic review. The left sided column begins with topics/sections such as: title, abstract, introduction, and methods, and ends with results, discussion, and funding. The four-phase flow diagram (Appendix A) is a graphic representation that includes the identification of records through database searching, screening and exclusion of the records, eligibility of and exclusion of articles, and inclusion of qualitative and/or quantitative studies. 


\section{Method}

The purpose of this systematic review was to examine the influence of depression on the postoperative pain experience. This systematic review considered randomized controlled trials (RCT’s), however in the absence of RCT’s, a quasi-experimental design, and, prospective cohort studies were included. Inclusion criteria for the systematic review consisted of: adults $\geq 18$ years of age with self-reported depression, subjects who have mild, moderate, or severe postoperative pain, subjects who received anesthesia or analgesia, and who underwent ambulatory surgery. The exclusion criteria for the systematic review consisted of subjects with three or more pre-existing comorbidities, subjects with a history of chronic pain, subjects with a history of substance abuse, studies not in the English language, and studies conducted before the year 2000. The exclusion criterion selected are a result of preliminarily identifying extrinsic factors that may influence postoperative pain management, and therefore limiting the intended purpose of identifying depression as a primary variable.

A search strategy utilized collected data from several databases including PubMed, Medline, CINAHL, and PsyINFO. Search terms included depression, post-surgical pain management, post-surgical pain, surgical procedures, medication management, anesthesia, postoperative outcomes. After screening the literature, nine studies were identified to be used to synthesize the information for the systematic review. Once all selected articles were gathered, they underwent the four-phase flow diagram as described in the theoretical framework section to further refine and include the best literature for the systematic review. Limitations to the review include lack of RCT's, which provide the highest level of evidence in research. Other limitations include additional extrinsic variables that may 
influence postoperative pain management aside from depression, such as anxiety, increased opioid tolerance, and physiological abnormalities.

RCT's for inclusion in this systematic review were appraised using the Critical Appraisal Skills Programme (CASP) checklist. The CASP checklist includes ten questions for evaluating literature to be included in the systematic review and helps determine the validity of results, comprehension of the results, and whether the results can be applied to a population (Critical Appraisal Skills Programme [CASP], 2017). The data collected for the systematic review was analyzed, screened, synthesized, following the PRISMA checklist, followed by a summary of the evidence, limitation of the review and conclusions. The research findings were disseminated December 11, 2018 in an electronic poster session at Rhode Island College, School of Nursing. 


\section{Results}

The results in this systematic review contain a heterogeneous mixture among study designs, study characteristics, exposure and outcome measures, methodology, and overall analytical data. Nine studies were included in this review, and thus synthesizing the results from the studies for this review required a systematic approach for reporting findings. In the following analysis findings were collected and reported based on commonality. Sample characteristics are described in the review and includes results relative to the common demographic information collected from the nine studies. Demographic details include age, gender, weight/body mass index, race, and education level, all of which were co-variables reported in exposure and outcome measures. Moreover, common clinical characteristics and outcome measures among all studies are systematically reported relative to surgery type, postoperative pain rescues, and preoperative depressive versus pain outcomes.

\section{Sample Characteristics}

The major study characteristics included in this review are found in Appendix B.

All nine studies excluded participants $<18$ years of age, and the age ranged from 18 to 80 years with the average age of $56.6 \pm 5.0$ among study participants. Riddle et al. (2015) was the only one that accounted for race in a total knee arthroscopy study, $82.7 \%$ white, 14.2\% black, and 3.1\% other. However, these racial demographics were included as covariates for their role in influencing pain outcomes, but no results were reported in the study. Regarding gender, two of the nine studies exclusively included women ranging from 122 to 1499, and one study did not include gender. Of the remaining six studies 
including both men and women, male population samples ranged from 36 to 186, and females from 25 to 617, demonstrating males and females were recruited in unequal numbers. Six studies included body mass index (BMI) or weight (Kg), with BMI ranging from $<18.5$ to $\geq 30$, and weights ranging from 45 to $96 \mathrm{~kg}$. The level of education among participants was included in three out of nine studies, and ranged from no formal education to college educated.

Age. 52 years old was an age cutoff indicator in the Caumo et al. (2002) study. $85.2 \%$ of participants $\leq 52$ years old reported absent or mild pain, while $43.3 \%$ of participants $\leq 52$ years old reported moderate or intense pain. $14.7 \%$ of participants $>52$ years old reported absent or mild pain, while $56.7 \%$ of participants $>52$ years old reported moderate or intense pain. In this study, a univariate analysis was used to correlate potential predicators of pain, and acute postoperative pain. Therefore, depression exposure and/or outcome measures were not associated with age. In the Kinjo et al. (2012) study, depression and age were independently measured against pain and opioid use. Ages included in the study were 65 and older, however 80 years or older was the cutoff score used to report results in the form of a path analysis. The direct effect on pain was -0.111 on postoperative day (POD) 1 and -0.046 on POD 2. Similarly, there was an indirect opioid use on POD 1 of -0.021 , and -0.017 on POD 2.

In another study by Kim et al. (2016), 29.3\% of patients were $\leq 44$ years of age, $52.6 \%$ of patients ages were between 45 and 59 , and $18.1 \%$ were $\geq 60$ years old. Among patients with severe definite depressive symptoms (Center of Epidemiological Studies [CES-D] $\geq 25), 21.9 \%$ were $\leq 44$ years old, $26.4 \%$ were between 45 and 69 , and $21.4 \%$ were $\geq 60$ years old. Participants in the same study with probable clinical depression 
$(\mathrm{CES}-\mathrm{D} \geq 16), 52.4 \%$ of patients were $\leq 44$ years of age, $58.9 \%$ of patients ages were between 45 and 59, and 57.2\% were $\geq 60$ years old. Pain score outcomes were correlated with preoperative CES-D scores, and not age.

The mean age of participants with or without depression in the Lanitis et al. (2015) study was 63.49 (depression/group B), and 55.65 (no depression/group A) respectively. In conjunction with other variables, overall, group B experienced more pain than group A. Similar results were found in Torres-Claramunt et al, (2017). In this study, 48 participants endorsed to depression with a mean age of 70.7. Of the remaining 755 non-depressed participants, the mean age was 72.6. Age was a covariate used for epidemiological data. No correlation was made between depression and age, however participants in the depressed group resulted in higher mean pain scores.

Gender. Among studies that included both male and female genders, and the univariate relationship to pain or depression, females tended to have more preoperative depression symptoms and postoperative pain. Research by Caumo et al. (2002) found 69.9\% of females reported absent or mild pain, and $79.3 \%$ of females reported moderate or intense pain. $30.1 \%$ of males reported absent or mild pain, and $20.7 \%$ of males reported moderate or intense pain. Moreover, Riddle et al. (2015) reported that $60.6 \%$ of women reported unilateral knee pain compared to 39.4\% of men. Using path analysis, Kinjo et al. (2012) reported that gender had both direct and indirect effects on pain and opioid use. Female pre-op pain scores measured to be 0.129 . Pain on POD 1 were both direct and indirect, measuring 0.138 and 0.027 respectively. On POD 2 pain was indirect, measuring at 0.102 . Indirect effects of opioid use on POD 1 was 0.030 , and on POD2 0.031. Thus, the female gender was associated with increased postoperative pain and 
opioid consumption. Moreover, Lanitis et al. (2015) reported 51.8\% of females had no depression (group A), and 74.6\% reported depression (group B). Conversely, 48.2\% of males reported no depression (group A), and 25.4\% reported depression (group B). Similar data from Torres-Claramunt et al. (2017) reported 91.7\% of depressed patients were female, while $8.3 \%$ of male patients were depressed. No correlation was made between depressed patients, gender, and associated pain outcomes in the TorresClaramunt et al. (2017) study.

Weight/Body Mass Index. Lanitis et al. (2015) included weight (kg) as a covariate in depression groups. Both depressed and non- depressed groups shared similar average weights. Of the 323 non-depressed participants, the average weight was 75.53 kg, compared to the 63 depressed participants with a weight of $74.86 \mathrm{~kg}$. Body mass index (BMI) was included in other studies in order to account for both weight and height, and this was measured in $\mathrm{kg} / \mathrm{m}^{2}$. Kim et al. (2016) categorized BMI into five groups: $<18.5 \mathrm{~kg} / \mathrm{m}^{2}, 18.5-22.9 \mathrm{~kg} / \mathrm{m}^{2}, 23-24.9 \mathrm{~kg} / \mathrm{m}^{2}, 25-29.9 \mathrm{~kg} / \mathrm{m}^{2}$, and $\geq 30 \mathrm{~kg} / \mathrm{m}^{2}$. The group with the largest number of participants, with CES-D scores $\geq 25$ (severe depression), had BMI’s between $18.5-22.9 \mathrm{~kg} / \mathrm{m}^{2}$. The largest group of participants with CES-D scores $\geq 16$ (probable clinical depression), also had BMI’s between 18.5-22.9 $\mathrm{kg} / \mathrm{m}^{2}$. Contrarily, the group with the smallest number of participants with CES-D scores $\geq 25$ (severe depression), had BMI's $<18.5 \mathrm{~kg} / \mathrm{m}^{2}$. The smallest group with CES-D scores $\geq 16$ (probable clinical depression), also had BMI's $<18.5 \mathrm{~kg} / \mathrm{m}^{2}$. Thus, a majority of participants in the study with probable or clinically severe depression fell within the same weight classes, with no major causal relationship inferred among other weight classes as it relates to depression and pain outcomes. Other studies that also included BMI as a 
covariate in depression were reported by Torres-Claramunt et al. (2017). In this study, depressed patients had a mean BMI of $31.5 \mathrm{~kg} / \mathrm{m}^{2}$, and non-depressed patients had a BMI of $31.4 \mathrm{~kg} / \mathrm{m}^{2}$, therefore no significant distinction could be concluded between depressed and non-depressed participants as it relates to BMI. According to Riddle et al. (2015), the average BMI of patients undergoing unilateral knee pain was $30.0 \mathrm{~kg} / \mathrm{m}^{2}$, and no causal relationship to depression or pain were reported in this study. Overall, no causal relationship could be inferred among studies that included weight and BMI as potential covariable influencers of depression or postoperative pain.

Education Level. Few studies included formal education as a characteristic or a potential variable that may affect overall pain scores. Caumo et al. (2002) included formal education which ranged from grades 0 -12. In this study mean formal education in years averaged at $6.65 \pm 4.29$. On the lower end, those participants with 0 to 3 formal years of education, $20.9 \%$ of participants self-reported absent or mild pain, while $13.3 \%$ of participants endorsed to moderate to intense pain. Among participants with 4 to 8 years of formal education, 55\% had absent to mild pain, while $56 \%$ of participants had moderate or intense pain. Moreover, of the participants with 9 to 12 formal years of education, $24 \%$ had absent or mild pain, and $26.7 \%$ endorsed to moderate to intense pain. Overall, although participants with 0-3 years of education demonstrated lower percentage rates of moderate or intense pain relative to absent or no pain, participants with 4-12 years reported higher percentage rates of moderate to intense pain relative to absent or no pain, and study results showed no significant relationship between formal years of education and acute postoperative pain outcomes. 
Kim et al (2016) and Lanitis et al (2015) included education levels ranging from junior high school to college, and they compared these education levels against depression groups. Kim et al (2016) found that approximately twenty-eight percent of participants with less than a high school education scored $\geq 25$ (severe depression) on the CES-D scale, and $59.9 \%$ scored $\geq 16$ (probable clinical depression). Among high school educated participants, $24.2 \%$ scored $\geq 25$ on the CES-D scale, and $57.8 \%$ within the same education classification scored $\geq 16$. Moreover, $22.2 \%$ of participants with a college education or more scored $\geq 25$ on the CES-D scale, and $54.1 \%$ scored $\geq 16$ respectively. Generally, participants with higher levels of education, as described above, demonstrated percentage rates lower than less educated participants among both CES-D classifications. Similarly, Lanitis et al. (2015) defined education levels as low (reached junior high) or high (senior school or above). Among participants with low education, $32.7 \%$ were categorized as having no depression, with $54.7 \%$ categorized as having depression. Inversely, $67.3 \%$ of higher educated participants were not depressed, with the remaining 45.3\% having depression. No correlation was made in this study as to education and pain levels, however pain and depression was comparatively analyzed.

\section{Surgical Characteristics, Pain Outcomes, and Narcotic Consumption}

In conjunction with depression, additional exposures and common clinical characteristics may have played a role in influencing pain outcomes. Per the results summarized in Appendix E, the type of procedure, anesthetic technique, pain consumption/management, and level of preoperative depression individually or collectively were analyzed comparatively against pain results. Six of the nine studies reported positive findings of higher postoperative pain levels among participants who had 
increased preoperative depression, including a systematic review conducted by Dadgostar et al. (2017) which reported an additional eight out of 18 studies demonstrating similar positive findings. In contrast, three out of nine studies reported a negative correlation including a systematic review conducted by Dadgostar et al. (2017), in which 10 of 18 studies reported a negative influence of depression on postoperative pain. The following studies in this systemic review will further detail the results of pain outcomes as it relates to surgical procedures and depression.

Surgical Characteristics. Surgical procedures associated with positive postoperative pain findings include abdominal, gynecological, non-cardiac, general, ears/nose/throat, orthopedic, and total knee arthroplasty. According to Caumo et al. (2002), 29 participants with moderate to intense depressive symptoms, and 167 who endorsed to mild depressive symptoms also had either absent or mild pain. Conversely, 51 participants reported moderate to intense depressive symptoms, and 99 endorsed to mild depressive symptoms, but reported moderate to intense pain. Additional confounding variables within the study associated with higher pain levels included female gender, age $>52$, 4-8 years of formal education, previous surgeries, neural block anesthesia, lower abdominal surgery, surgeries $\leq 3$ hours, intraoperative fentanyl doses $>$ $7.81 \mu \mathrm{g} / \mathrm{kg}$, postoperative analgesic administration (non-opioid plus opioid), no epidural analgesia, and low-trait anxiety levels.

Although six of nine studies demonstrated a positive correlation between preoperative depression and postoperative pain outcomes, three out of nine studies reported a negative correlation including a systematic review conducted by Dadgostar et al. (2017), in which 10 of 18 studies reported a negative influence of depression on 
postoperative pain. Procedures listed among these studies that showed no correlation included: breast and lymph node, dental and maxillary, ENT, cardiac, total knee arthroscopies, and hysterectomy surgeries. Breast/axillary surgery, total knee arthroscopy, and lumbar surgery were studies included in this review that shared similar negative findings.

Pain Outcomes. According to Lanitis et al. (2015), pain outcomes were measured using the NRS and VAS rating scales, and they were measured 1 day after surgery at 6 different time intervals. Group A (no depression) had overall lower preoperative and postoperative pain scores than Group B (depression). The second pain assessment was associated with the highest NRS and VAS scores in both groups, with Group A NRS score of 3.31, and VAS score of 3.29. Group B reported higher results at the second pain assessment with Group B NRS of 4.43, and Group B VAS of 4.40. In both groups, VAS and NRS pain scores declined during subsequent pain assessments. Interestingly, narcotic use was highest in Group A with narcotic use of (88.6\%) and analgesic use of (83.1\%). Group B narcotic use of 63.5\%, and analgesic use of $68.3 \%$. Further research comparing pain outcomes in depressed and non-depressed participants with concurrent use of pain management interventions was reported by Torres-Claramunt et al. (2017). Ninety four percent of participants using the geriatric depression scale (GDS) were clinically non-depressed with a mean VAS pain score of 1.1, maximum VAS pain score of 1.6, and required pain management with an average of 1.8 rescues. Conversely, $6 \%$ of the remaining participants were clinically depressed with a mean VAS score of 2.0, maximum VAS score of 5.3, and required additional pain management with a mean of 4.4 rescues. 
Chaichana et al. (2011) utilized two scales to measure preoperative depression, the Zung self-rating depression scale and the MSPQ score (Appendix E). Pain outcomes were measured using the VAS, accounting separately for both back (BP) and leg pain (LP). Preoperative mean depression and postoperative pain scores were higher, and throughout the 12-month follow-up period showed an overall decline in all reported findings. Increases in the preoperative Zung self-rating depression scale and the MSPQ scores were associated with lower improvement in overall VAS scores, however these findings were not statistically significant.

In another study conducted by Kim et al. (2016), pain outcomes were measured one hour after surgery and again on POD 1. Using the CES-D scale for depression, 24.1\% of participants scored $\geq 25$ with a mean of $18.5 \pm 9.7$, which corresponded with severe depressive symptoms. Postoperative pain scores $\geq 4$ (NRS) one hour after surgery, were $5.8 \pm 1.7$, this accounted for $91.2 \%$ of the participants. NRS scores $\geq 4$ decreased one day after surgery to $2.2 \pm 1.2$, in $13.4 \%$ of the participants. In this study, participants did not demonstrate increased pain outcomes as a result of higher levels of depression.

Similar trends in pain outcomes despite perioperative depression was reported by Riddle et al. (2015). Using the CES-D cutoff score of $\geq 16,11.8 \%$ of participants were categorized as having probable clinical depression. Mean preoperative depressive symptoms were 7.3, with an improved mean postoperative CES-D score of 6.74. CES-D scores were measured against knee injury and osteoarthritis score (KOOS), a pain scale that also included pre-and postoperative measurements. The KOOS scale ranged from 0 to 100 , with 0 indicating severe function limiting pain, and 100 indicating no pain. Associated improvements in pain scores were reported as a preoperative mean KOOS of 
65.85, followed by better postoperative outcomes evidenced by a mean KOOS score of 84.84. Although postoperative depression was not a primary focus in this review by Riddle et al. (2015), overall improvement was reported in both depression and pain outcomes.

Narcotic Consumption. A study analyzing morphine consumption and postoperative pain scores in abdominal/gynecologic procedures was conducted by Cohen et al. (2005). A positive correlation between preoperative psychosocial factors and postoperative pain was evidenced by increased morphine consumption and increased psychosocial measures 48-hours after surgery, and at 4 weeks post operation. Additional evidence is supported by Kinjo et al. (2012), who examined multiple surgeries, a majority of which involved orthopedic, neurological, urologic, gynecological, and general procedures. Study results reported greater overall pain scores in patients with higher preoperative depression scores, of which $16.6 \%$ of patients were on anti-depressants. Preoperative depression had more of a direct effect on preoperative pain levels (0.110), and more of an indirect effect on POD 1 and 2 (0.023 and 0.038). Depression symptoms were lower among participants who received IV or PO opioid doses, however opioid use was still reported as an indirect measure on POD 1 and POD 2 (0.004 and 0.008). Generally, higher pain levels and opioid doses (IV/PO) were immediately reported on POD 1 compared to preoperative pain levels but declined on POD 2.

Overall, the results of the nine selected studies included in this systematic review were nonconclusive. Lanitis et al. (2015), Torres-Claramunt et al. (2017), Caumo et al. (2002), Cohen et al. (2005), and Kinjo et al. (2012) were among the studies that demonstrated a positive relationship between depression and postoperative pain outcomes. 
In contrast, studies conducted by Chaichana et al. (2011), Kim et al. (2016), and Riddle et al. (2015) correlated negative findings between depression and postoperative outcomes. Dadgostar et al. (2017) reported mixed results of both positive and negative findings, similar to this conducted systematic review. 


\section{Summary and Conclusions}

The purpose of this systematic review was to examine the influence of depression on the postoperative pain experience. No evidence among studies conclusively isolated depression as the sole variable in the influence of postoperative pain. Overall, nine studies were included this this review, six of which reported positive findings in the influence of depression on postoperative pain outcomes, and another three studies reported negative findings. Due to an insufficient number of randomized control trials (RCT's) available, this meta-analysis included one RCT, five prospective cohort studies, one longitudinal study, one comparative cohort study, and a systematic review with a similar clinical question. Fortunately, additional research studies were obtained to expand the findings of the included Dadgostar et al. (2017) systematic review.

This study proved technically difficult to conduct as a result of a high degree of heterogeneity in study methods, surgical procedure types, exposure and outcome measures, and co-variable clinical characteristics. Procedure types that yielded positive findings between depression and pain included: general surgery, abdominal surgery, total knee arthroscopy, and various other non-cardiac surgeries. Procedure types that reported negative findings between depression and pain included: lumbar surgery, total knee arthroscopy, and various other surgeries included in the systematic review conducted by Dadgostar et al. (2017), noted in Appendix E. Overall, no conclusive evidence or causal relationship among the types of surgeries relative to depression and postoperative pain outcomes were posited in there heterogeneous studies. 
Covariables that influenced preoperative depression levels and postoperative pain outcomes were factored into each study, however the results among these characteristics varied, and did not directly correlate each covariable to the reported outcomes. Co-variable clinical characteristics that may have influenced exposure and outcome measures included mean age of $56.6 \pm 5.0$, female gender, and lower education levels, as evidenced in studies conducted by Caumo et al. (2002), Kim et al. (2016), Kinjo et al. (2012), Lanitis et al. (2015), and Torres-Claramunt et al. (2017). Weight and BMI results were reported differently among Kim et al. (2016), Lanitis et al. (2015), and Torres-Claramunt et al. (2017), however the inclusion of these variables and lack clinical correlation increased ambiguity within the study findings.

Furthermore, the degree of heterogenicity among depression scores and pain outcome measures are reported in Appendix B. At least 11 depression scales, and 10 pain scales were utilized with varying degrees of measurement and reported outcomes associated with depression and pain symptomology. Most studies in this review also included preoperative pain interventions, intraoperative anesthetic techniques, and postoperative pain management, including narcotic and analgesic consumption. Participants in all six studies that reported positive findings of depression on pain postoperatively received some form of pain intervention. Pain interventions included NSAIDS, neuraxial blockade, IV-PCA or epidurals with narcotics, or a combination of multimodal analgesia. Chiachana et al. (2011) and Riddle et al. (2015) reported negative findings of depression on postoperative pain. These studies did not include intraoperative anesthetic techniques, nor pain management interventions in the postoperative period. However, Kim et al. (2016) reported negative findings of depression on postoperative pain, 
participants received preoperative anxiolytics and postoperative NSAIDS as needed. Nonetheless, heterogenicity occurred among all studies that included anesthetic and pain management modalities in the preoperative, intraoperative, and postoperative periods.

Overall limitations in this review include the inability to obtain the highest level of evidence such as RCT’s. Due to lack of available RCT studies, cohort studies provided the primary basis of information on which this study relied. Cohort studies do not provide the highest level of evidence, and therefore an increased level of heterogenicity within this systematic review was apparent, often without a control group for comparison. The use of various methods to measure exposure and outcome measures also lead to little consensus. Population sample sizes also varied among the included studies which affected validity and generalizability of the findings. The length of follow up in which pain outcomes were measured differed among all studies, thus a standardized method to evaluate the duration of pain outcomes in the postoperative period was not consistent. Although depression scales were used to identify depression symptomology, no studies reported whether participants were previously diagnosed with clinical depression, nor was there a designated clinical diagnostic classification to identify depressed patients. Furthermore, age, female gender, and narcotic consumption may have influenced pain outcomes making it technically difficult to isolate the influence of the depression as a primary determinant in the outcome of the pain experience. 


\section{Recommendations and Implications for Advanced Nursing Practice}

More focused research, specifically RCT's, involving participants with clinically diagnosed depression and self-reported depression, are necessary to conclude postoperative pain outcomes. Depressive disorders as outlined by the latest diagnostic and statistical manual of mental disorders should be clinically diagnosed and documented as an inclusion criterion for study. Future studies should examine patient populations with known depression, and the effects this disorder has on neuronal pain pathways, pain tolerance and management, and analgesic drug therapy effectiveness. Further research should be conducted to determine the effectiveness of preoperative antidepressants in the reduction of pain management and medication requirements in the postoperative period.

This review highlights the numerous measures of depression and pain utilized in the clinical arena. Narrowing the measurement tools used to evaluate specific populations would provide an opportunity to evaluate depression and pain more effectively and compare outcomes across studies. Conducting studies utilizing similar patient populations may help to reduce confounding variables among participants and assist in identifying shared variables and important predictors in outcome measures. Improved research methods and consensus on measurement in focused populations will have the potential to strengthen comparison research techniques and aid future clinicians in managing postoperative pain in patients who may be predisposed to depression and an altered pain experience and duration. Future research on predictors of the post-operative 
pain experience may add to the important task of mitigating the emergent opioid epidemic. 


\section{References}

Alvin, M.D., Miller, J.A., Sundar, S., Lockwood, M., Lubelski, D., Nowacki, A.S., ... Mroz, T.E. (2015). The impact of preoperative depression on quality of life outcomes after posterior cervical fusion. The Spine Journal: Official Journal of the North American Spine Society, 15, 79-85.

http://doi: 10.1016/j.spinee.2014.07.001

American Pain Foundation. (2006). Voices of chronic pain survey. Retrieved from http://www.painmed.org/patientcenter/facts_on_pain.aspx\#refer

Carroll, I., Barelka, P., Wang, C.K.M., Wang, B.M., Gillespie, M.J., McCue, R., ... Younger, J.W. (2012). A pilot cohort study of the determinants of longitudinal opioid use after surgery. Anesth Analg, 115(3), 694-702.

http://doi: 10.1213/ANE.0b013e31825c049f

Caumo, W., Schmidt, A., Schneider, C., Bergman, J., Iwamoto, C.W., Adamatti, L.C., ... Ferreira, M.B.C. (2002). Preoperative predictors of moderate to intense acute postoperative pain in patients undergoing abdominal surgery. Acta Anaesthesiol Scand, 46, 1265-1271.

Chaichana, K.L., Mukherjee, D., Adogwa, O., Cheng, J.S., \& McGirt, M.J. (2011). Correlation of preoperative depression and somatic perception scales with postoperative disability and quality of life after lumbar discectomy. Journal of Neurosurgery Spine, 14(2), 261-267. http://doi:10.3171/2010.10.SPINE10190

Cohen, L., Fouladi, R.T., Katz, J. (2005). Preoperative coping strategies and distress predict postoperative pain and morphine consumption in women undergoing 
abdominal gynecologic surgery. J Psychosom Res, 58(2), 201209. http://doi: 10.1016/j.jpsychores.2004.07.007

Critical Appraisal Skills Programme. (2017). CASP systematic reviews checklist. Retrieved from http://docs.wixstatic.com/ugd/dded87_7e983a320087439e94533f4697aa109c.pdf

Cyranowski, J. M., Hofkens, T. L., Swartz, H. A., \& Gianaros, P. J. (2011). Thinking about a close relationship differentially impacts cardiovascular stress responses among depressed and nondepressed women. Health Psychology, 30(3), 276-284. http://dx.doi.org/10.1037/a0023005

Dadgostar, A., Bigder, M., Punjani, N., Lozo, S., Chahal, V., \& Kavanagh, A. (2017). Does preoperative depression predict post-operative surgical pain: A systematic review. International Journal of Surgery, 41, 162-173. https://doi.org/10.1016/j.jjsu.2017.03.061

Fishbain, D. A., Cutler, R., Rosomoff, H. L., \& Rosomoff, R. S. (1997). Chronic painassociated depression: antecedent or consequence of chronic pain? A review. Clin J Pain, 13(2), 116-137.

Ghoneim, M. M., \& O’Hara, M. W. (2016). Depression and postoperative complications: an overview. BMC Surgery, 16, 5. http://doi.org/10.1186/s12893-016-0120-y

Institute of Medicine. (2011). Institute of medicine report from the committee on advancing pain research, care, and education: Relieving pain in America, a blueprint for transforming prevention, care, education and research. The National 
Academies Press. Retrieved from

http://books.nap.edu/openbook.php?record_id=13172\&page=1

Institute of Medicine. (2011). Finding what works in health care: Standards for systematic reviews. The National Academies Press. Retrieved from https://www.ncbi.nlm.nih.gov/pubmedhealth/PMH0079447/

Kim, Y.S., Do, H., Lee, J.W., Jeong, J., Shin, Y.W., Yi, K., ... Kim, J. (2016). Patient reporting pain intensity immediately after surgery can be associated with underlying depression in women with breast cancer. Psychooncology, 25(3), 308315. http://doi: 10.1002/pon.3919

Kinjo, S., Sands, L. P., Lim, E., Paul, S., \& Leung, J. M. (2011). Prediction of postoperative pain using path analysis in older patients. Journal of Anesthesia, 26(1), 1-8.

Lanitis, S., Karkoulias, K., Pintireki, A., Sgourakis, G., Kouloura, A., ... Brotzakis, P. (2015). The impact of subclinical depression on the postoperative perception of pain in general surgery patients. Hellenic Journal of Surgery, 87, 317. https://doi.org/10.1007/s13126-015-0232-3

Magni,G., Moreschi,C., Rigatti-Luchini, S., Merskey, H. (1994). Prospective study on the relationship between depressive symptoms and chronic musculoskeletal pain. Pain. 56(3), 289-297.

Moher, D., Liberati, A., Tetzlaff, J., \& Altman, D.G. (2009). The PRISMA group preferred reporting items for systematic reviews and meta-analyses: the PRISMA 
statement. PLoS Med, 6(7), e1000097.

https://doi.org/10.1371/journal.pmed.1000097

ÖZalp, G., Sarioglu, R., Tuncel, G., Aslan, K., \& Kadiogullari, N. (2003). Preoperative emotional states in patients with breast cancer and postoperative pain. Acta Anaesthesiologica Scandinavica, 47, 26-29. http://doi:10.1034/j.13996576.2003.470105.x

Pratt L.A., \& Brody D.J. (2008). Depression in the United States household population. 2005-2006. NCHS Data Brief, (7), 1-8.

Riddle, D. L., Perera, R. A., Nay, W. T., \& Dumenci, L. (2015). What Is the Relationship Between Depressive Symptoms and Pain During Functional Tasks in Persons Undergoing TKA? A 6-year Perioperative Cohort Study. Clinical Orthopaedics and Related Research, 473(11), 3527-34.

Suffeda, A., Meissner, W., Rosendahl, J., \& Guntinas-Lichius, O. (2016). Influence of depression, catastrophizing, anxiety, and resilience on postoperative pain at the first day after otolaryngological surgery: a prospective single center cohort observational study. Medicine, 95(28), e4256. http://doi.org/10.1097/MD.0000000000004256

Surah, A., Baranidharan, G., \& Morley, S. (2014). Chronic pain and depression. Continuing Education in Anaesthesia Critical Care \& Pain,14(2), 85-89. https://doi.org/10.1093/bjaceaccp/mkt046

Torres-Claramunt, R., Hinarejos, P., Amestoy, J., Leal, J., Sanchez-Soler, J., Puig-Verdie, L., .. Monllau, J. (2017). Depressed patients feel more pain in the short term 
after total knee arthroplasty. Knee Surgery, Sports Traumatology, Arthroscopy:

Official Journal of the ESSKA, 25. http://doi: 10.1007/s00167-016-4418-1.

WHO. (2017). Retrieved June 13, 2017 from the World Health Organization

http://www.who.int/mediacentre/factsheets/fs369/en/ 


\section{Appendix A}

\section{PRISMA 2009 Flow Diagram}

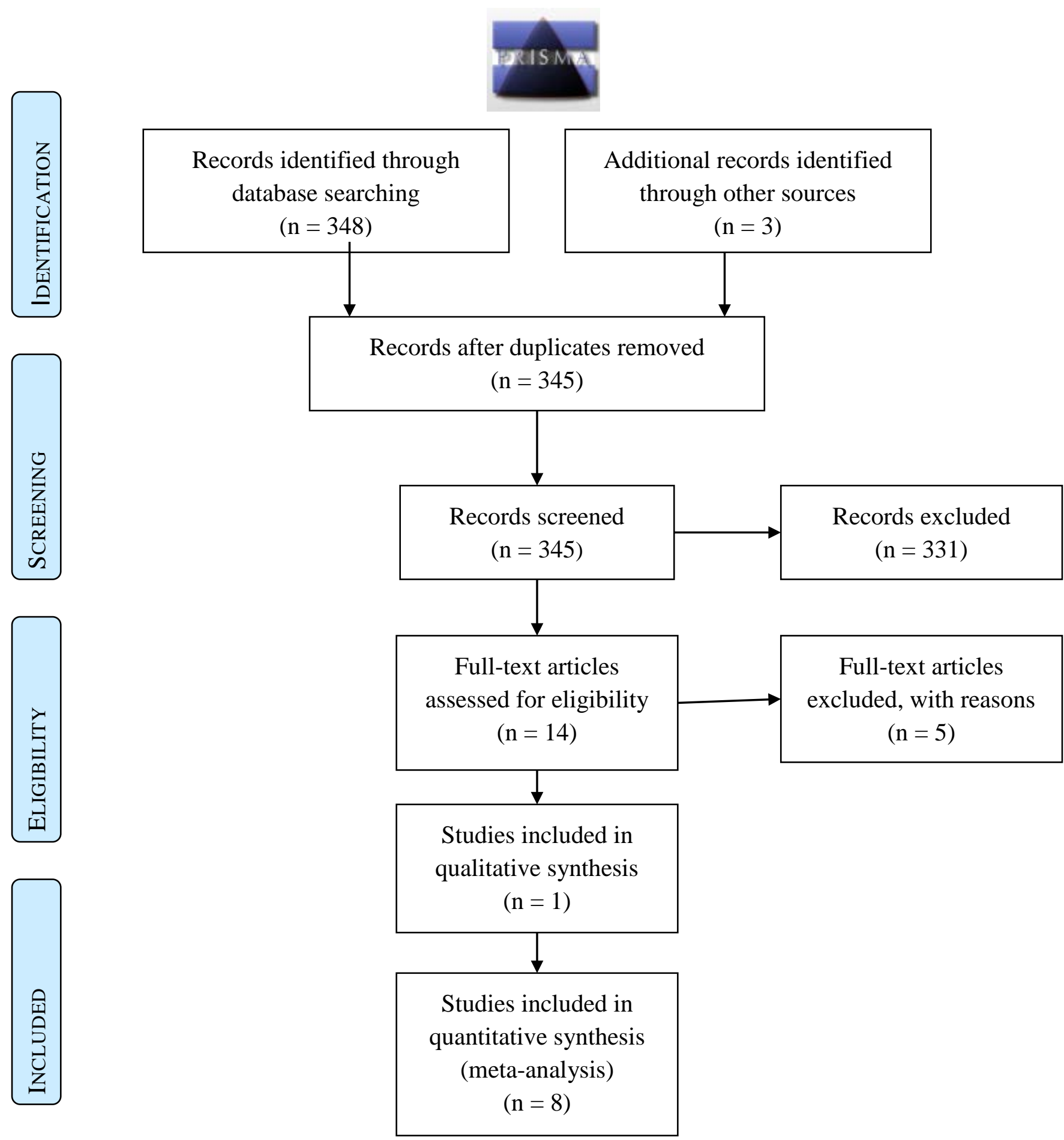




\section{Appendix B}

Study Characteristics

\begin{tabular}{|c|c|c|c|c|c|}
\hline & $\begin{array}{l}\text { Author, } \\
\text { Year }\end{array}$ & $\begin{array}{l}\text { \# of } \\
\text { Pts in } \\
\text { Study }\end{array}$ & Type of Procedure & Depression Scale & Pain Scale \\
\hline $\mathrm{a}$ & $\begin{array}{l}\text { Caumo et } \\
\text { al., } 2002\end{array}$ & 346 & Abdominal Surgery & $\begin{array}{c}\text { The Montgomery-Asberg Depression } \\
\text { Rating Scale }\end{array}$ & Visual Analog Scale \\
\hline $\mathrm{b}$ & $\begin{array}{l}\text { Chaichana } \\
\text { et al., } 2011\end{array}$ & 67 & Lumbar Surgery & $\begin{array}{c}\text { Zung Self-Rating Depression, } \\
\text { Modified Somatic Perception } \\
\text { Questionnaire }\end{array}$ & Visual Analog Scale \\
\hline C & $\begin{array}{l}\text { Cohen et } \\
\text { al., } 2005\end{array}$ & 122 & $\begin{array}{c}\text { Abdominal } \\
\text { Gynecologic Surgery }\end{array}$ & The Mental Health Inventory & The McGill Pain Questionnaire \\
\hline $\mathrm{d}$ & $\begin{array}{l}\text { Dadgostar } \\
\text { et al., } 2017\end{array}$ & 2540 & $\begin{array}{c}\text { Multiple/Various } \\
\text { Surgeries/Procedures }\end{array}$ & $\begin{array}{c}\text { Hamilton Depression Scale, Beck } \\
\text { Depression Index, Self-Rating } \\
\text { Questionnaire for Depression, Hospital } \\
\text { anxiety and Depression scale, 15-item } \\
\text { Geriatric Depression Scale, Major } \\
\text { Depressive Disorder Scale, German } \\
\text { Center of Epidemiological Studies } \\
\text { Depression Scale, Patient Health } \\
\text { Questionnaire }\end{array}$ & $\begin{array}{l}\text { Visual Analog Scale, Brief Pain } \\
\text { Inventory, Semmes-Weinstein } \\
\text { Mechanical Esthesiometer, Verbal } \\
\text { Rating Scale, 11-Point Numeric } \\
\text { Scale, 10-point Numeric Rating } \\
\text { Scale, Verbal Numeric Rating Scale, } \\
\text { Numerical Rating Scale, Quality } \\
\text { Improvement in Postoperative Pain } \\
\text { Management Scale }\end{array}$ \\
\hline $\mathrm{e}$ & $\begin{array}{l}\text { Kim et al., } \\
2016\end{array}$ & 1499 & $\begin{array}{l}\text { Breast and Axillary } \\
\text { Surgery }\end{array}$ & $\begin{array}{l}\text { Center of Epidemiological Studies } \\
\text { Depression Scale }\end{array}$ & 11- Point Numeric Rating Scale \\
\hline $\mathrm{f}$ & $\begin{array}{l}\text { Kinjo et al., } \\
2012\end{array}$ & 331 & $\begin{array}{c}\text { Multiple/Various } \\
\text { Surgeries/Procedures }\end{array}$ & 15-item Geriatric Depression Scale & 11-Point Numeric Rating Scale \\
\hline g & $\begin{array}{l}\text { Lanitis et } \\
\text { al., } 2015\end{array}$ & 400 & General Surgery & Hospital Anxiety and Depression Scale & $\begin{array}{l}\text { Visual Analog Scale 10-point } \\
\text { Numeric Rating Scale }\end{array}$ \\
\hline $\mathrm{h}$ & $\begin{array}{l}\text { Riddle et } \\
\text { al., } 2015\end{array}$ & 4796 & $\begin{array}{l}\text { Total Knee } \\
\text { Arthroscopy }\end{array}$ & $\begin{array}{c}\text { Center of Epidemiological Studies } \\
\text { Depression Scale }\end{array}$ & $\begin{array}{l}\text { Knee Injury and Osteoarthritis } \\
\text { Outcome Score }\end{array}$ \\
\hline
\end{tabular}




\begin{tabular}{c|c|c|c|c}
$\begin{array}{c}\text { Torres- } \\
\text { Claramunt }\end{array}$ & 803 & $\begin{array}{c}\text { Total Knee } \\
\text { Arthroplasty }\end{array}$ & Geriatric Depression Scale Short Form & Visual Analog Scale
\end{tabular}

et al., 2017 


\section{Appendix C}

Study Appraisal

\begin{tabular}{|c|c|c|c|c|c|c|c|}
\hline & $\begin{array}{c}\text { Author, } \\
\text { Year }\end{array}$ & Study Type & $\begin{array}{l}\text { Inclusion } \\
\text { Criteria }\end{array}$ & Exclusion Criteria & Strengths & Limitations & Appraisal \\
\hline $\mathrm{a}$ & $\begin{array}{c}\text { Caumo } \\
\text { et al., } \\
2002\end{array}$ & $\begin{array}{c}\text { Prospective } \\
\text { Cohort } \\
\text { Study }\end{array}$ & $\begin{array}{l}\text { ASA grade } \\
\text { I-III, } \\
\text { Undergoing } \\
\text { elective } \\
\text { abdominal } \\
\text { surgery, Age } \\
18-60\end{array}$ & $\begin{array}{c}\text { Medical history of } \\
\text { brain damage. Mental } \\
\text { retardation or } \\
\text { psychiatric disorder. } \\
\text { Not speaking } \\
\text { Portuguese. } \\
\text { Difficulty } \\
\text { understanding verbal } \\
\text { commands. Use of } \\
\text { preanesthetic } \\
\text { medications. Renal } \\
\text { transplantation. } \\
\text { Laparoscopic surgery }\end{array}$ & $\begin{array}{l}\text { Evaluators were } \\
\text { not aware of the } \\
\text { study objectives } \\
\text { thus limiting } \\
\text { interview bias. } \\
\text { Use of the highest } \\
\text { quartile to define } \\
\text { depressive } \\
\text { symptoms in } \\
\text { patients with a } \\
\text { diagnostic } \\
\text { depressive illness. } \\
\text { Comprehensive } \\
\text { assessment of the } \\
\text { average } \\
\text { postoperative pain } \\
\text { using different } \\
\text { time periods to } \\
\text { provide a global } \\
\text { score. }\end{array}$ & $\begin{array}{c}\text { Independent } \\
\text { predictors of acute } \\
\text { postoperative pain } \\
\text { were not obtained } \\
\text { prior to the } \\
\text { multivariate } \\
\text { analysis. } \\
\text { The inability to } \\
\text { exclude subjects } \\
\text { with anxiety from } \\
\text { the study limited } \\
\text { the ability to } \\
\text { isolate the } \\
\text { relationship } \\
\text { between } \\
\text { depression as a } \\
\text { sole psychological } \\
\text { influence of } \\
\text { postoperative } \\
\text { pain. }\end{array}$ & $\begin{array}{l}\text { Clearly focused study } \\
\text { with an acceptable } \\
\text { cohort recruited. } \\
\text { Exposure outcome } \\
\text { measures utilized } \\
\text { validated objective } \\
\text { scales. Confounding } \\
\text { variable were adjusted } \\
\text { with multivariate } \\
\text { analysis. All subjects } \\
\text { remained in the study, } \\
\text { length of exposure } \\
\text { and outcomes were } \\
\text { limited to 24-48hrs. } \\
\text { Precise results with } \\
\text { 95\% CI (1.36-2.15). } \\
\text { Study evidence } \\
\text { appears sufficient. } \\
\text { Portuguese conducted } \\
\text { study and results may } \\
\text { not be applicable to } \\
\text { local population. } \\
\text { Consistent with } \\
\text { evidence comparable }\end{array}$ \\
\hline
\end{tabular}




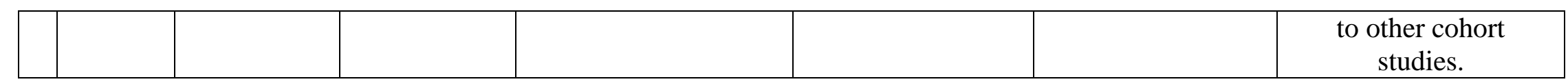




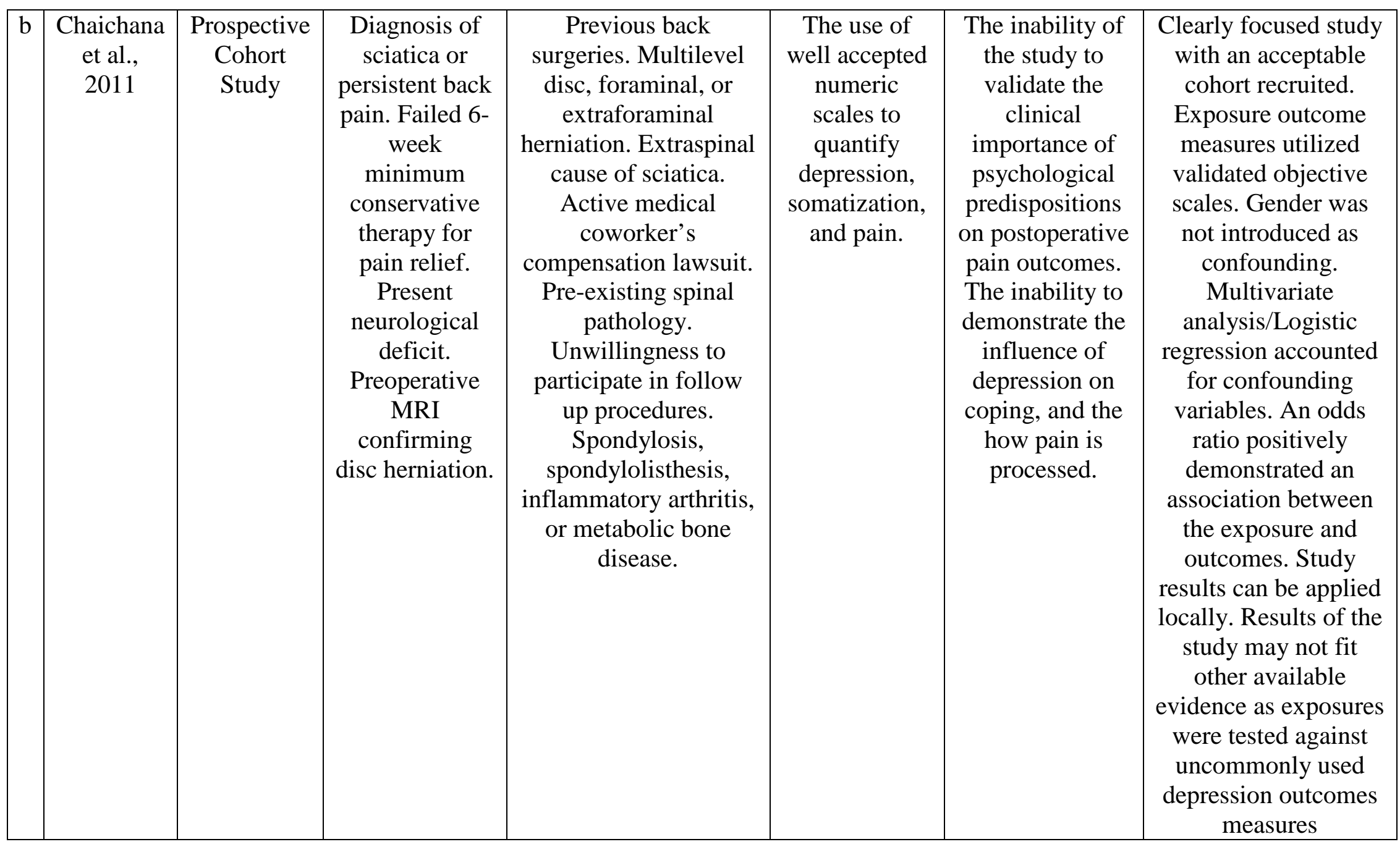




\begin{tabular}{|c|c|c|c|c|c|c|c|}
\hline C & $\begin{array}{l}\text { Cohen } \\
\text { et al., } \\
2005\end{array}$ & $\begin{array}{c}\text { Randomized } \\
\text { Double- } \\
\text { Blinded } \\
\text { Placebo- } \\
\text { Controlled }\end{array}$ & $\begin{array}{c}\text { Major } \\
\text { gynecological } \\
\text { surgical. } \\
\text { Procedure by } \\
\text { laparotomy. } \\
\text { ASA I-II, Ages } \\
\text { 19-75, weight } \\
\text { 45-90 kg, } \\
\text { height } 150-175 \\
\text { cm, BMI } \leq 30 \text {, } \\
\text { and the ability } \\
\text { to speak and } \\
\text { read English. }\end{array}$ & $\begin{array}{l}\text { Contraindications } \\
\text { to PCA morphine } \\
\text { or regional } \\
\text { anesthesia. History } \\
\text { of major } \\
\text { psychiatric } \\
\text { disorder, history of } \\
\text { a substance use } \\
\text { disorder, and } \\
\text { current opioid use. }\end{array}$ & $\begin{array}{l}\text { The use of the } \\
\text { regression analysis } \\
\text { using the sensory } \\
\text { pain rating index } \\
\text { from the MPQ as the } \\
\text { measure of pain } \\
\text { allowed for a } \\
\text { stronger association } \\
\text { of preoperative } \\
\text { psychosocial factors. } \\
\text { The study included } \\
\text { several preoperative } \\
\text { psychosocial } \\
\text { measures to evaluate } \\
\text { coping mechanisms, } \\
\text { as opposed to solely } \\
\text { evaluating } \\
\text { pharmacological } \\
\text { therapy. }\end{array}$ & $\begin{array}{c}\text { Lack of } \\
\text { presurgical pain } \\
\text { levels included in } \\
\text { the study. } \\
\text { The term } \\
\text { “preoperative } \\
\text { distress” is poorly } \\
\text { defined and does } \\
\text { not isolate } \\
\text { depression as an } \\
\text { independent } \\
\text { psychosocial } \\
\text { variable. It is not } \\
\text { possible to infer } \\
\text { causality between } \\
\text { the preoperative } \\
\text { psychosocial } \\
\text { measures, and } \\
\text { postoperative } \\
\text { pain levels and } \\
\text { morphine } \\
\text { consumption. } \\
\text { Loss of patients } \\
\text { by week } 4 \text { may } \\
\text { have introduced } \\
\text { relative selection } \\
\text { bias into the } \\
\text { study. }\end{array}$ & $\begin{array}{c}\text { Clearly focused } \\
\text { study with an } \\
\text { acceptable cohort } \\
\text { recruited. Exposure } \\
\text { outcome measures } \\
\text { utilized validated } \\
\text { objective scales. } \\
\text { Initially n=122 were } \\
\text { enrolled, } 4 \text { weeks } \\
\text { follow up n=71. } \\
\text { Groups variables } \\
\text { consistent from start } \\
\text { of trial. Subjects and } \\
\text { personnel blinded to } \\
\text { treatment. } \\
\text { Interventions treated } \\
\text { equally within } \\
\text { experimental group. } \\
\text { No utilization of } \\
\text { valid depression } \\
\text { scales affected } \\
\text { generalizability. } \\
\text { Treatment outcome } \\
\text { difficult to assess. } \\
\text { Study evidence } \\
\text { appears sufficient. }\end{array}$ \\
\hline
\end{tabular}




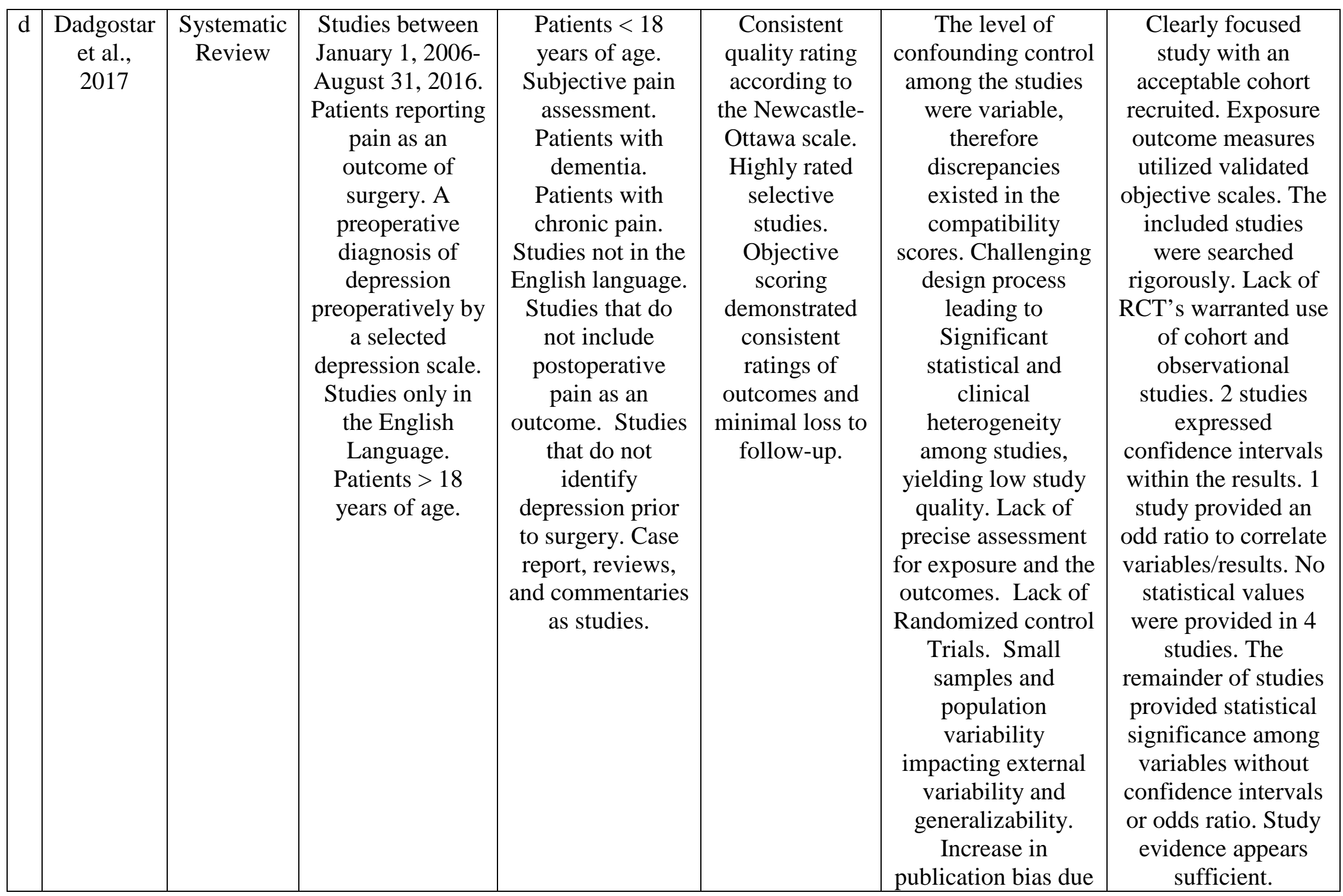




\begin{tabular}{|l|l|l|l|l|l|}
\hline & & & & $\begin{array}{c}\text { to lack of non- } \\
\text { English studies, } \\
\text { non-full text studies, } \\
\text { unpublished data. }\end{array}$ & \\
\hline
\end{tabular}




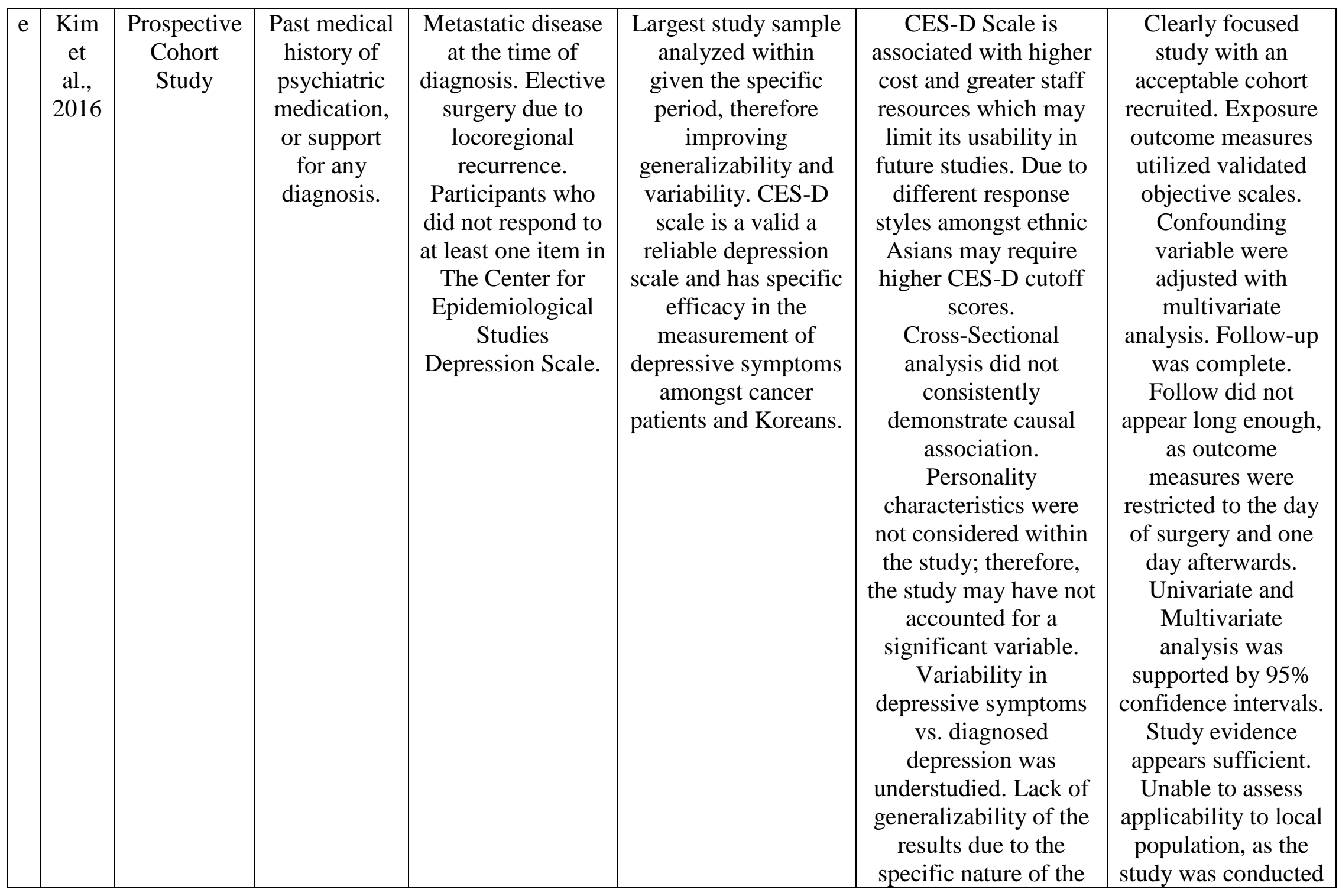




\begin{tabular}{|l|l|l|l|l|c|c|}
\hline & & & & & $\begin{array}{c}\text { study of breast cancer } \\
\text { patients. }\end{array}$ & $\begin{array}{c}\text { in South Korea with } \\
\text { subsets of Asian } \\
\text { ethnic groups. }\end{array}$ \\
\hline
\end{tabular}




\begin{tabular}{|c|c|c|c|c|c|c|c|}
\hline $\mathrm{f}$ & $\begin{array}{l}\text { Kinjo } \\
\text { et al., } \\
2012\end{array}$ & $\begin{array}{c}\text { Prospective } \\
\text { Cohort } \\
\text { Study }\end{array}$ & $\begin{array}{l}65 \text { years of age or } \\
\text { more. Have } \\
\text { undergone elective } \\
\text { noncardiac surgery } \\
\text { requiring at least } 2 \\
\text { postoperative days in } \\
\text { the hospital. Must be } \\
\text { English speaking. } \\
\text { Must be able to } \\
\text { provide consent. } \\
\text { Patients who received } \\
\text { oral pain analgesia or } \\
\text { intravenous patient- } \\
\text { controlled analgesia } \\
\text { postoperatively. }\end{array}$ & $\begin{array}{l}\text { Patients who } \\
\text { received } \\
\text { postoperative } \\
\text { neuraxial } \\
\text { analgesia or } \\
\text { peripheral } \\
\text { nerve blocks. }\end{array}$ & $\begin{array}{l}\text { This study } \\
\text { utilized path } \\
\text { modeling as a } \\
\text { statistical } \\
\text { analysis } \\
\text { allowing } \\
\text { assessment of } \\
\text { the direct and } \\
\text { indirect } \\
\text { effects of } \\
\text { predictors on } \\
\text { the dependent } \\
\text { variables. }\end{array}$ & $\begin{array}{l}\text { The Numeric Pain } \\
\text { Scale may have not } \\
\text { captured the entirety of } \\
\text { pain perception. } \\
\text { Postoperative pain was } \\
\text { measured once daily } \\
\text { which may have led to } \\
\text { failure to capture } \\
\text { fluctuations in pain. } \\
\text { The study did not } \\
\text { include other } \\
\text { psychological and } \\
\text { emotional factors that } \\
\text { may modulate pain, } \\
\text { thus isolating } \\
\text { depression as a sole } \\
\text { variable. No } \\
\text { differentiation was } \\
\text { made between pain } \\
\text { types within the study. } \\
\text { Generalizability was } \\
\text { limited to oral } \\
\text { analgesics, IV-PCA } \\
\text { opioids, or patients } \\
\text { with major surgeries. }\end{array}$ & $\begin{array}{l}\text { Clearly focused } \\
\text { study with an } \\
\text { acceptable cohort } \\
\text { recruited. Exposure } \\
\text { outcome measures } \\
\text { utilized validated } \\
\text { objective scales. } \\
\text { Confounding } \\
\text { variable were } \\
\text { assessed with path } \\
\text { analysis. Follow-up } \\
\text { was complete. } \\
\text { Follow-up length } \\
\text { limited to } \\
\text { postoperative day } 1 \\
\text { \& 2. Unable to tell if } \\
\text { follow-up was long } \\
\text { enough or warranted } \\
\text { further evaluation. } \\
\text { Precision of results } \\
\text { are unknown as } \\
\text { statistical } \\
\text { significance were } \\
\text { included, and } \\
\text { confidence intervals } \\
\text { and odds ratio were } \\
\text { not. Study evidence } \\
\text { appears sufficient. } \\
\text { Results may be } \\
\text { applicable locally. }\end{array}$ \\
\hline
\end{tabular}




\begin{tabular}{|c|c|c|c|c|c|c|c|}
\hline $\mathrm{g}$ & $\begin{array}{c}\text { Lanitis } \\
\text { et al., } \\
2015\end{array}$ & $\begin{array}{c}\text { Prospective } \\
\text { Cohort } \\
\text { Study }\end{array}$ & $\begin{array}{l}\text { Consensual } \\
\text { agreement in } \\
\text { the study. } \\
\text { Interviewed } \\
\text { by trained } \\
\text { doctor in the } \\
\text { study. }\end{array}$ & $\begin{array}{l}\text { Intubation after } \\
\text { surgery. In } \\
\text { ability to } \\
\text { comprehend or } \\
\text { complete } \\
\text { questionnaires. }\end{array}$ & $\begin{array}{l}\text { The inclusion of } \\
\text { all known } \\
\text { predictors of } \\
\text { postoperative } \\
\text { pain avoided bias } \\
\text { due to } \\
\text { confounding } \\
\text { variables. } \\
\text { Anxiety was } \\
\text { eliminated as a } \\
\text { cofounding } \\
\text { variable to solely } \\
\text { determine } \\
\text { relationship of } \\
\text { depression as an } \\
\text { independent } \\
\text { factor of pain. }\end{array}$ & $\begin{array}{c}\text { Significant } \\
\text { differences } \\
\text { between gender, } \\
\text { age, anxiety, level } \\
\text { of education, use of } \\
\text { analgesics, and } \\
\text { narcotics produced } \\
\text { wide variability in } \\
\text { results } \\
\text { necessitating the } \\
\text { use of a } \\
\text { multivariate } \\
\text { analysis. }\end{array}$ & $\begin{array}{l}\text { Clearly focused study } \\
\text { with an acceptable cohort } \\
\text { recruited. Exposure } \\
\text { outcome measures } \\
\text { utilized validated } \\
\text { objective scales. } \\
\text { Confounding variable } \\
\text { were adjusted with } \\
\text { multivariate analysis. } \\
\text { Unable to assess the } \\
\text { follow-up of } 14 \text { subjects } \\
\text { within the study. No } \\
\text { explanation provided as } \\
\text { to failed attrition, } \\
\text { therefore it is difficult to } \\
\text { tell if the follow-up was } \\
\text { complete enough. Follow } \\
\text { up did not occur on the } \\
\text { day of operation, it } \\
\text { occurred day } 1 \text { after } \\
\text { surgery. Outcomes } \\
\text { measured } 6 \text { times during } \\
\text { day } 1 \text { of surgery. Follow- } \\
\text { up does not appear long } \\
\text { enough. Study evidence } \\
\text { appears sufficient. } \\
\text { Statistical significance } \\
\text { was provided within the } \\
\text { study; however, no } \\
\text { confidence interval or } \\
\text { odds ratio correlated the }\end{array}$ \\
\hline
\end{tabular}




\begin{tabular}{|l|l|l|l|l|l|c|}
\hline & & & & & & $\begin{array}{c}\text { data. Results appear } \\
\text { applicable locally. }\end{array}$ \\
\hline
\end{tabular}




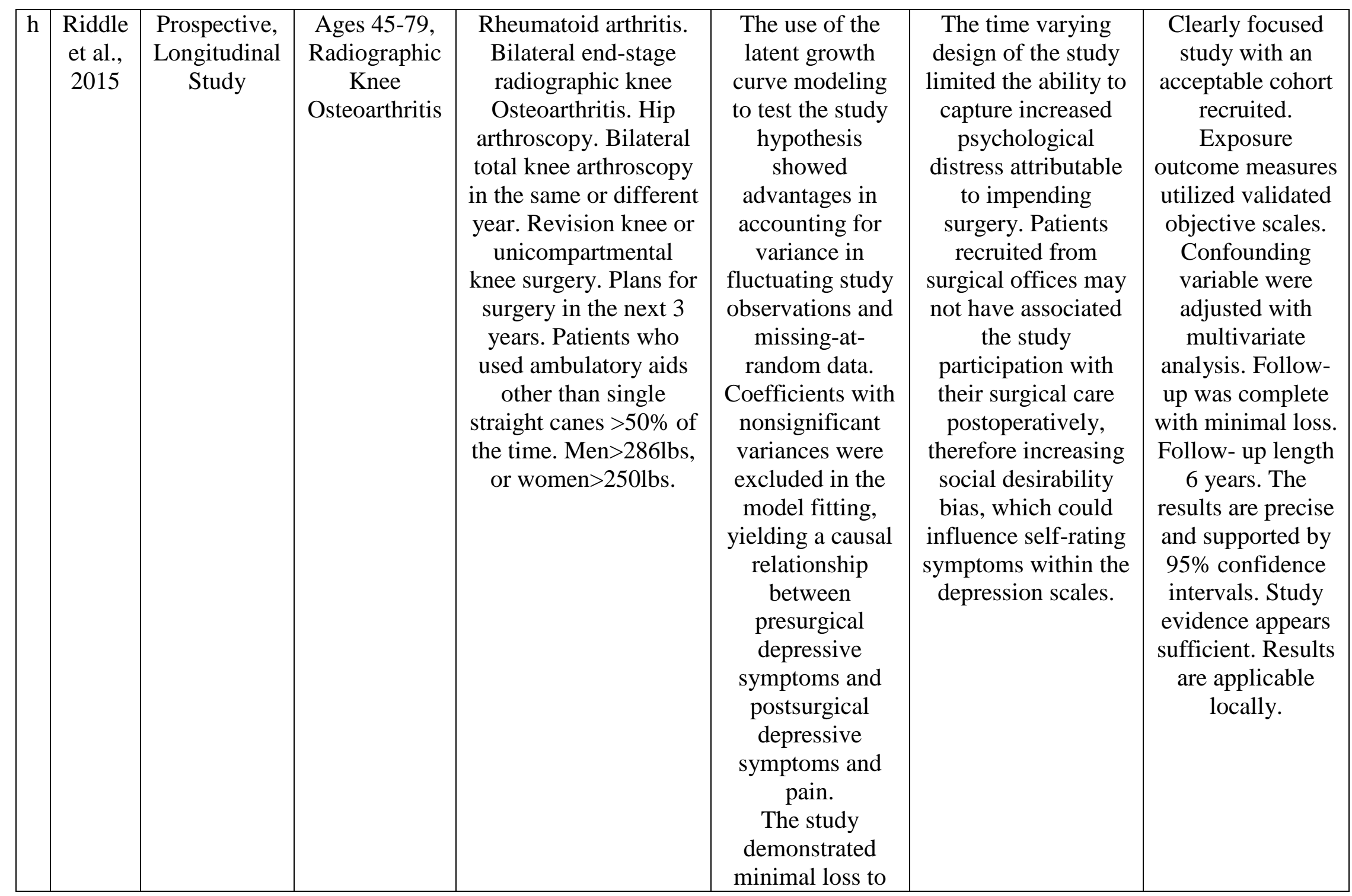




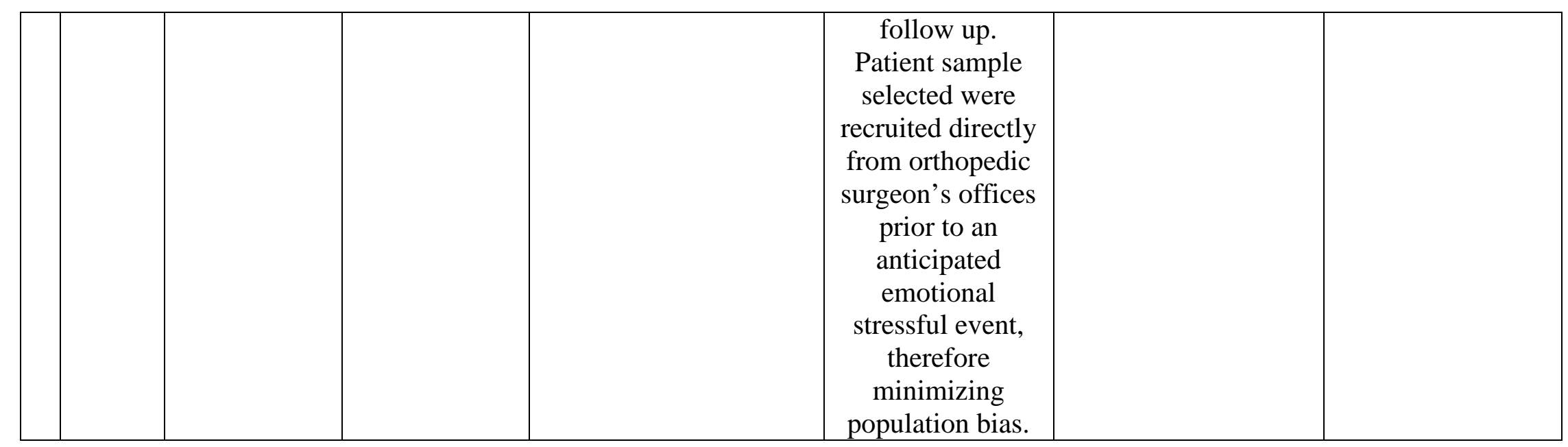




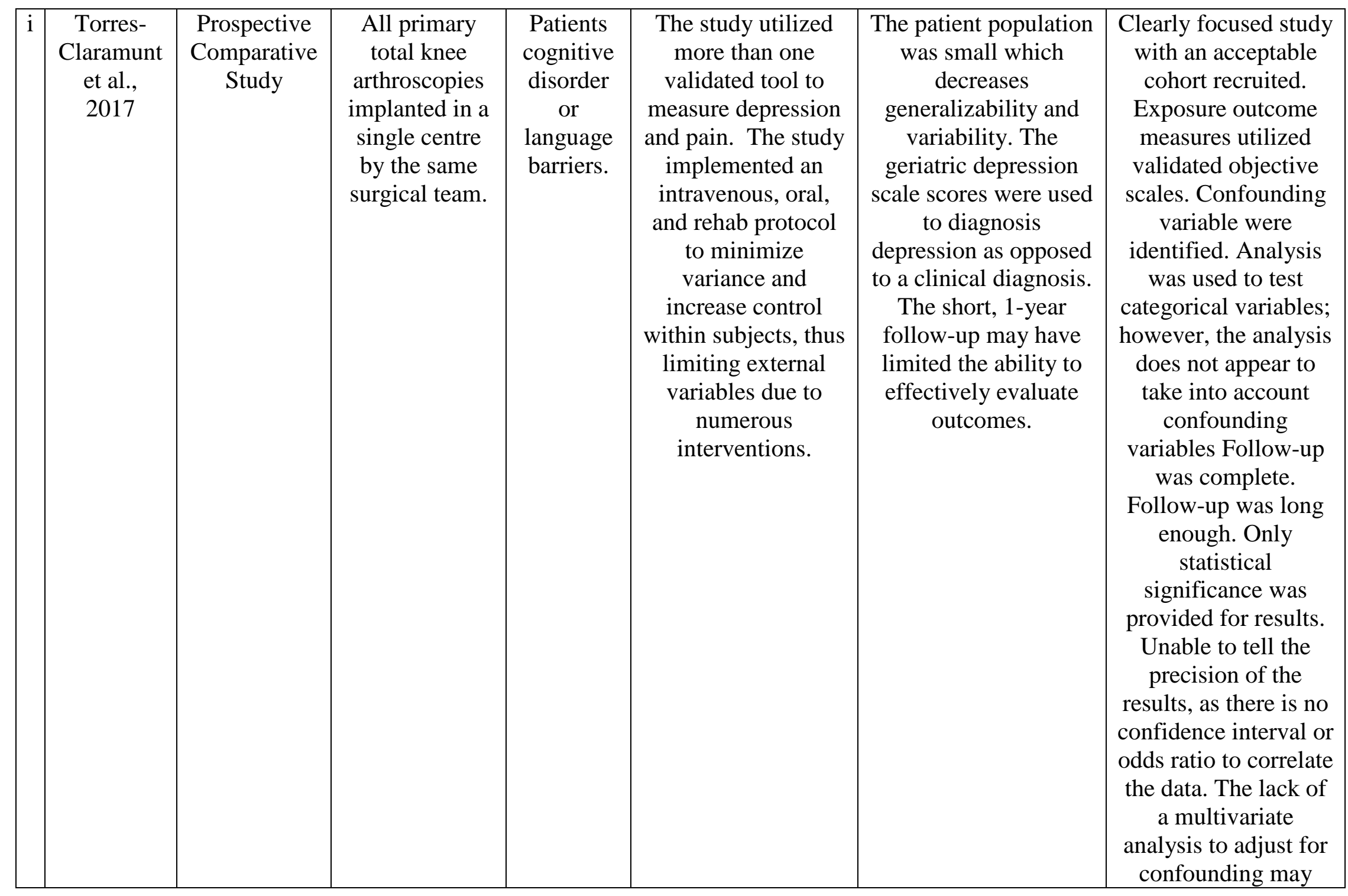




\begin{tabular}{|l|l|r|r|r|r|}
\hline & & & & have provided \\
insufficient data \\
evidence. A small \\
sample size, and \\
spanish conducted \\
S
\end{tabular}




\section{Appendix D}

CASP Table

\begin{tabular}{|c|c|c|c|c|c|c|c|c|c|}
\hline & $\begin{array}{l}\text { Author } \\
\text {,Year }\end{array}$ & Study Type & $\begin{array}{l}\text { Are } \\
\text { the } \\
\text { result } \\
\text { s of } \\
\text { the } \\
\text { study } \\
\text { valid? }\end{array}$ & $\begin{array}{c}\text { Cohort } \\
\text { recruitment } \\
\text { acceptable? }\end{array}$ & $\begin{array}{c}\text { Exposure, } \\
\text { Outcome } \\
\text { Measures, } \\
\text { Bias } \\
\text { Minimization }\end{array}$ & $\begin{array}{l}\text { Adjustment } \\
\text { for } \\
\text { confounding } \\
\text { factors, } \\
\text { design/ } \\
\text { analysis }\end{array}$ & $\begin{array}{l}\text { Subject } \\
\text { follow-up } \\
\text { strength/ } \\
\text { length }\end{array}$ & $\begin{array}{l}\text { Results of the } \\
\text { study/precision? }\end{array}$ & $\begin{array}{l}\text { Applicability } \\
\text { Implications }\end{array}$ \\
\hline $\mathrm{a}$ & $\begin{array}{l}\text { Caumo } \\
\text { et al., } \\
2002\end{array}$ & $\begin{array}{c}\text { Prospective } \\
\text { Cohort } \\
\text { Study }\end{array}$ & Yes & $\begin{array}{c}\text { Tertiary } \\
\text { Care } \\
\text { University } \\
\text { Hospital, } \\
\text { Local } \\
\text { Ethics } \\
\text { Committee } \\
\text { Approval, } \\
\text { Written } \\
\text { Consent }\end{array}$ & $\begin{array}{c}\text { Objective } \\
\text { measures } \\
\text { were utilized. } \\
\text { Exposure } \\
\text { measure } \\
\text { include } \\
\text { MADRS } \\
\text { depression } \\
\text { scale. } \\
\text { Outcome } \\
\text { measure } \\
\text { include VAS } \\
\text { in patients } \\
\text { undergoing } \\
\text { abdominal } \\
\text { surgery. }\end{array}$ & $\begin{array}{l}\text { Confounding } \\
\text { variable } \\
\text { were } \\
\text { adjusted } \\
\text { with } \\
\text { multivariate } \\
\text { analysis }\end{array}$ & $\begin{array}{l}\text { All subjects } \\
\text { remained in } \\
\text { the study, } \\
\text { length of } \\
\text { exposure } \\
\text { and } \\
\text { outcomes } \\
\text { were } \\
\text { limited to } \\
\text { 24-48hrs }\end{array}$ & $\begin{array}{l}\text { Precise results with } \\
\text { 95\% CI (1.36-2.15). } \\
\text { Study evidence } \\
\text { appears sufficient. } \\
\text { The mean (+/-SD) } \\
\text { of depression } \\
\text { symptoms was } \\
\text { 8.32+/-8.17. All } \\
\text { subjects graded } \\
\text { depression (mood) } \\
\text { and pain as either } \\
\text { mild, moderate, or } \\
\text { severe in intensity. } \\
\text { Among subjects } \\
\text { with mild to } \\
\text { moderate mood } \\
\text { intensity, } 29 \text { of } 167 \\
\text { subjects endorsed to } \\
\text { absent or mild pain, } \\
\text { and } 51 \text { of } 99\end{array}$ & $\begin{array}{l}\text { Consistent } \\
\text { with } \\
\text { evidence } \\
\text { comparable } \\
\text { to other } \\
\text { cohort } \\
\text { studies. } \\
\text { Portuguese } \\
\text { conducted } \\
\text { study and } \\
\text { results may } \\
\text { not be } \\
\text { applicable to } \\
\text { local } \\
\text { population. }\end{array}$ \\
\hline
\end{tabular}




\begin{tabular}{|l|l|l|l|l|l|l|}
\hline & & & & & $\begin{array}{c}\text { subjects endorsed to } \\
\text { moderate to intense } \\
\text { pain. Depression } \\
\text { (mood) symptoms } \\
\text { were related to } \\
\text { reports of higher } \\
\text { levels of } \\
\text { postoperative pain. }\end{array}$ \\
\hline
\end{tabular}




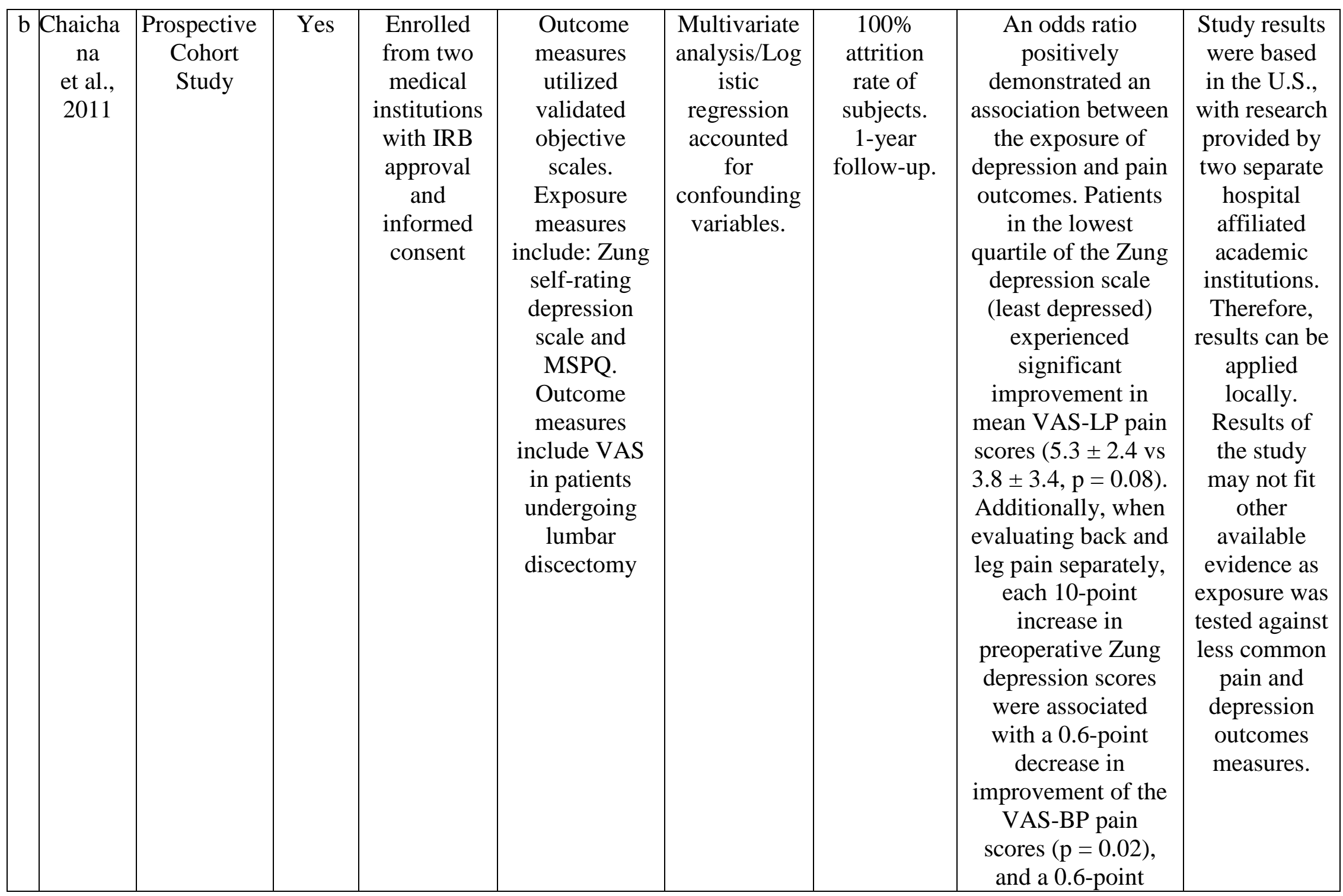




\begin{tabular}{|l|l|l|l|l|l|l|l|}
\hline & & & & & & $\begin{array}{c}\text { decrease in } \\
\text { improvement of the } \\
\text { VAS-LP pain scores } \\
(\mathrm{p}=0.03) .\end{array}$ \\
\hline
\end{tabular}




\begin{tabular}{|c|c|c|c|c|c|c|c|c|c|}
\hline C & $\begin{array}{c}\text { Cohen } \\
\text { et al., } \\
2005\end{array}$ & $\begin{array}{c}\text { Randomized } \\
\text { Double- } \\
\text { Blinded } \\
\text { Placebo- } \\
\text { Controlled }\end{array}$ & Yes & $\begin{array}{c}\text { Approval } \\
\text { by the } \\
\text { Toronto } \\
\text { Hospital } \\
\text { Committee } \\
\text { for } \\
\text { Research } \\
\text { on Human } \\
\text { Subjects. }\end{array}$ & $\begin{array}{c}\text { Outcome } \\
\text { measures } \\
\text { utilized } \\
\text { validated } \\
\text { objective } \\
\text { scales. } \\
\text { Exposure } \\
\text { measures } \\
\text { include the } \\
\text { MHI. } \\
\text { Outcome } \\
\text { measures } \\
\text { include MPQ } \\
\text { in patients } \\
\text { undergoing } \\
\text { abdominal } \\
\text { gynecologic } \\
\text { surgery. Three } \\
\text { separate } \\
\text { interventions } \\
\text { introduced }\end{array}$ & $\begin{array}{l}\text { Groups } \\
\text { variables } \\
\text { adjusted for } \\
\text { effects of } \\
\text { other } \\
\text { medical } \\
\text { factors and } \\
\text { concurrent } \\
\text { variables. } \\
\text { Concurrent } \\
\text { variables or } \\
\text { adjustment } \\
\text { methods not } \\
\text { detailed } \\
\text { within the } \\
\text { study. }\end{array}$ & $\begin{array}{c}\text { Initially } \\
\text { n=122 were } \\
\text { enrolled, } 4 \\
\text { weeks } \\
\text { follow up } \\
\text { n=71. }\end{array}$ & $\begin{array}{l}\text { Subjects and } \\
\text { personnel were } \\
\text { blinded to } \\
\text { treatment. } \\
\text { Interventions were } \\
\text { treated equally } \\
\text { within experimental } \\
\text { groups. Several } \\
\text { scales were utilized } \\
\text { to identify subject } \\
\text { exposure to } \\
\text { depressive } \\
\text { symptoms. The } \\
\text { exposures } \\
\text { demonstrated a } \\
\text { correlational } \\
\text { relationship to } \\
\text { outcome measures } \\
\text { related to pain. } \\
\text { Morphine } \\
\text { consumption after } \\
\text { surgery (P=.027) } \\
\text { and self-distraction } \\
\text { coping (P=.039) } \\
\text { were independently } \\
\text { positively } \\
\text { associated with 48-h } \\
\text { pain rating index } \\
\text { (PRI-T) scores. } \\
\text { Concurrent } \\
\text { Negative affect }\end{array}$ & $\begin{array}{c}\text { No } \\
\text { utilization of } \\
\text { conventional } \\
\text { depression } \\
\text { scales within } \\
\text { the study, } \\
\text { therefore } \\
\text { generalizabili } \\
\text { ty was } \\
\text { affected. } \\
\text { Treatment } \\
\text { outcomes } \\
\text { difficult to } \\
\text { assess. Study } \\
\text { evidence } \\
\text { appears } \\
\text { sufficient. }\end{array}$ \\
\hline
\end{tabular}




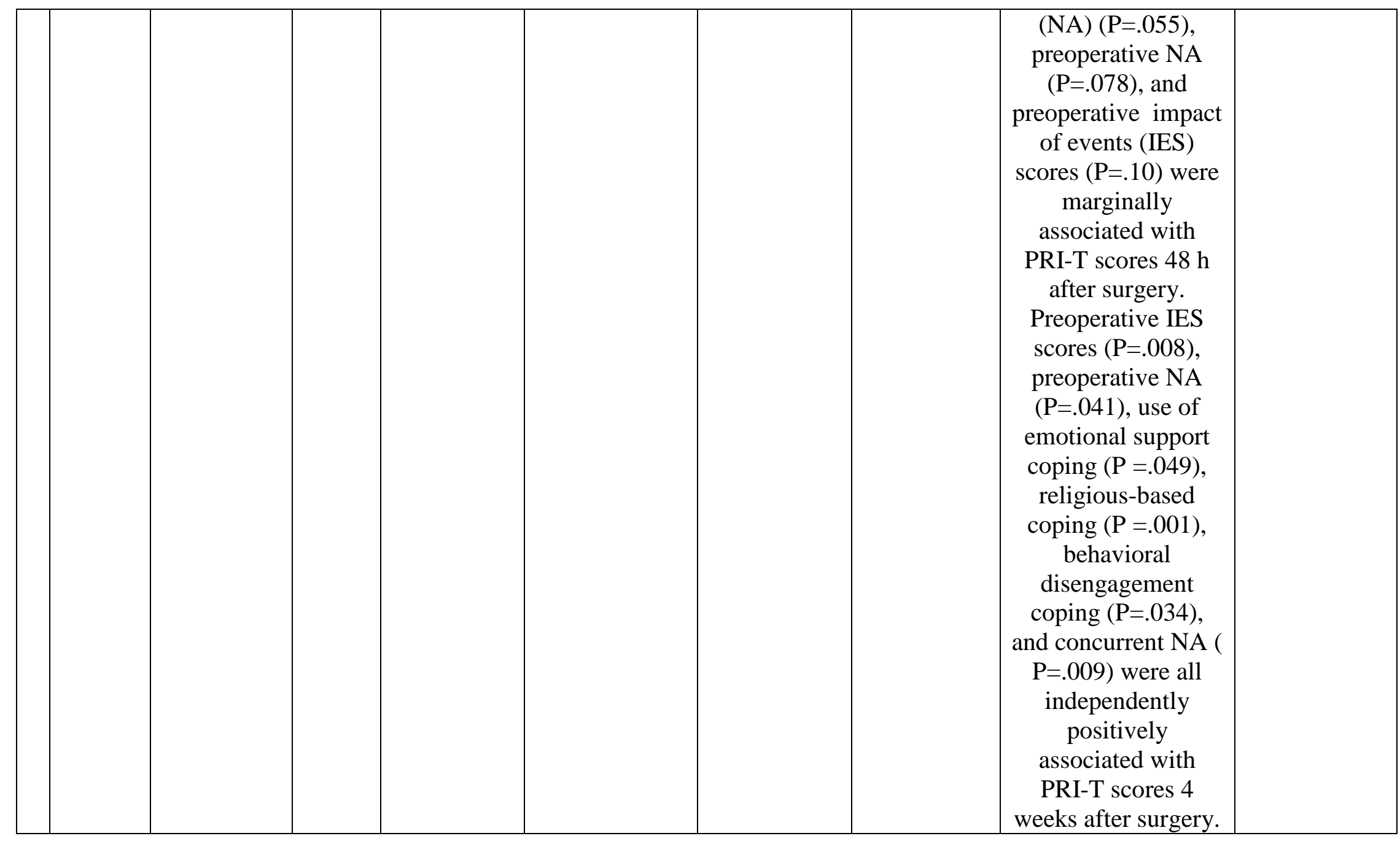




\begin{tabular}{|c|c|c|c|c|c|c|c|c|c|}
\hline $\mathrm{d}$ & $\begin{array}{c}\text { Dadgo } \\
\text { star et } \\
\text { al., } \\
2017\end{array}$ & $\begin{array}{c}\text { Systematic } \\
\text { Review }\end{array}$ & Yes & $\begin{array}{c}\text { Yes, No } \\
\text { IRB } \\
\text { approval } \\
\text { required. } \\
\text { Data } \\
\text { collected } \\
\text { through } \\
\text { search } \\
\text { databases, } \\
\text { and } \\
\text { processes } \\
\text { using two } \\
\text { independen } \\
\text { t reviewers } \\
\text { and a third- } \\
\text { party } \\
\text { arbitrator. }\end{array}$ & $\begin{array}{c}\text { Exposure and } \\
\text { outcome } \\
\text { measures } \\
\text { utilized } \\
\text { validated } \\
\text { objective } \\
\text { scales. } \\
\text { Multiple } \\
\text { measures } \\
\text { utilized over } \\
18 \text { selected } \\
\text { articles with } \\
\text { various } \\
\text { surgeries } \\
\text { involved. }\end{array}$ & $\begin{array}{l}\text { The level of } \\
\text { confounding } \\
\text { control } \\
\text { among the } \\
\text { studies were } \\
\text { variable, } \\
\text { therefore } \\
\text { discrepancie } \\
\text { s existed in } \\
\text { the } \\
\text { compatibilit } \\
\text { y scores. }\end{array}$ & $\begin{array}{c}\text { Not } \\
\text { applicable. }\end{array}$ & $\begin{array}{c}\text { Lack of RCT's } \\
\text { warranted use of } \\
\text { cohort and } \\
\text { observational } \\
\text { studies. } 2 \text { studies } \\
\text { expressed } \\
\text { confidence intervals } \\
\text { within the results. } 1 \\
\text { study provided an } \\
\text { odd ratio to } \\
\text { correlate } \\
\text { variables/results. No } \\
\text { statistical values } \\
\text { were provided in } 4 \\
\text { studies. The } \\
\text { remainder of studies } \\
\text { provided statistical } \\
\text { significance among } \\
\text { variables without } \\
\text { confidence intervals } \\
\text { or odds ratio. } 8 \text { out } \\
\text { of } 18 \text { studies } \\
\text { reported a positive } \\
\text { effect of depression } \\
\text { on postoperative } \\
\text { pain scores totaling } \\
1314 \text { patients. } \\
\text { Procedure types } \\
\text { demonstrating these } \\
\text { positive effects } \\
\text { included: gastric }\end{array}$ & $\begin{array}{l}\text { Study } \\
\text { evidence } \\
\text { appears } \\
\text { sufficient. } \\
\text { The scale } \\
\text { and studies } \\
\text { were vastly } \\
\text { heterogenous } \\
\text {. The study } \\
\text { lacks } \\
\text { generalizabili } \\
\text { ty. }\end{array}$ \\
\hline
\end{tabular}




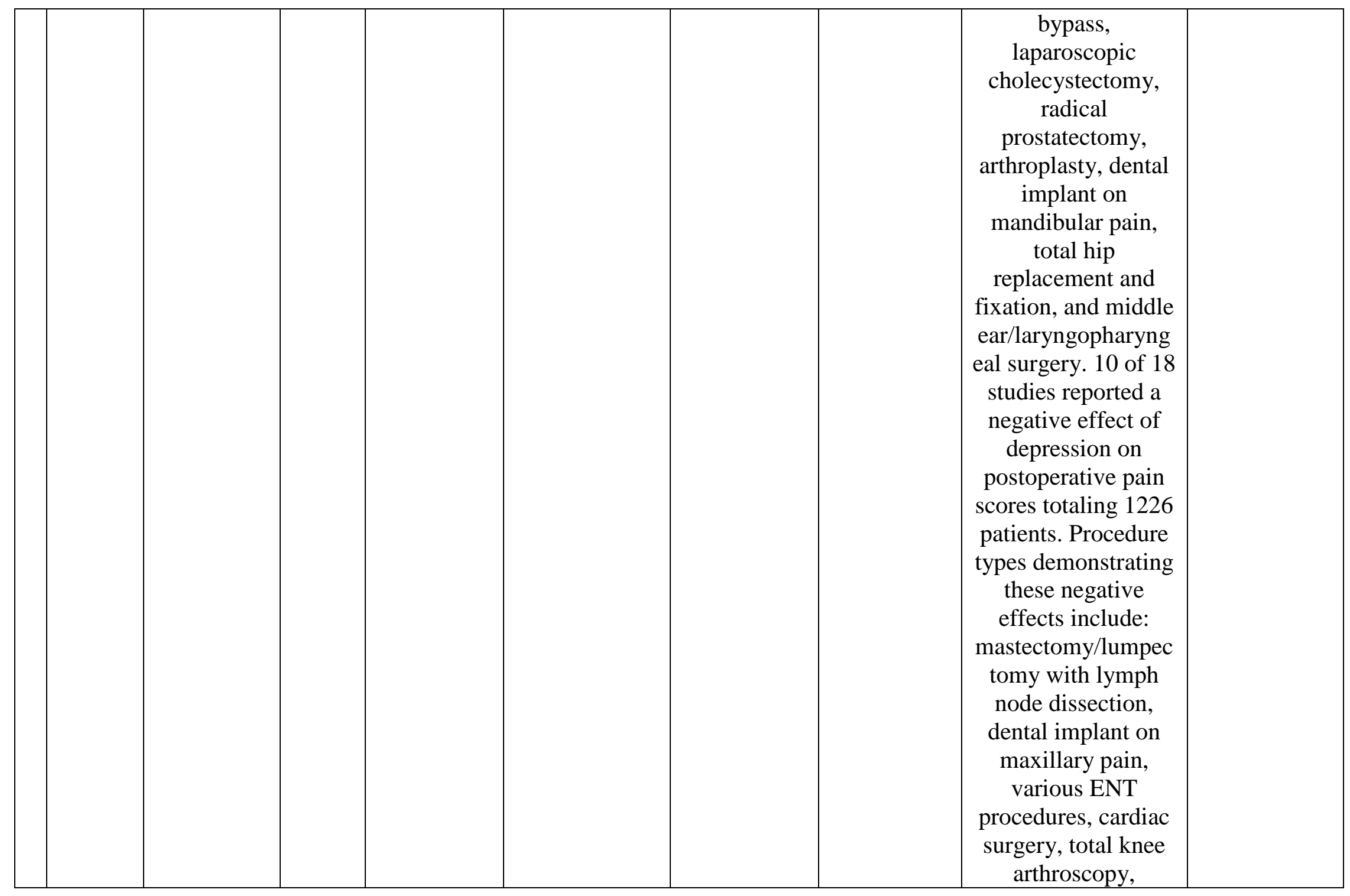




\begin{tabular}{|l|l|l|l|l|l|l|l|}
\hline & & & & & & & $\begin{array}{c}\text { elective cardiac } \\
\text { surgery, and } \\
\text { laparoscopic } \\
\text { hysterectomy. }\end{array}$ \\
& & & & & & & \\
\hline
\end{tabular}




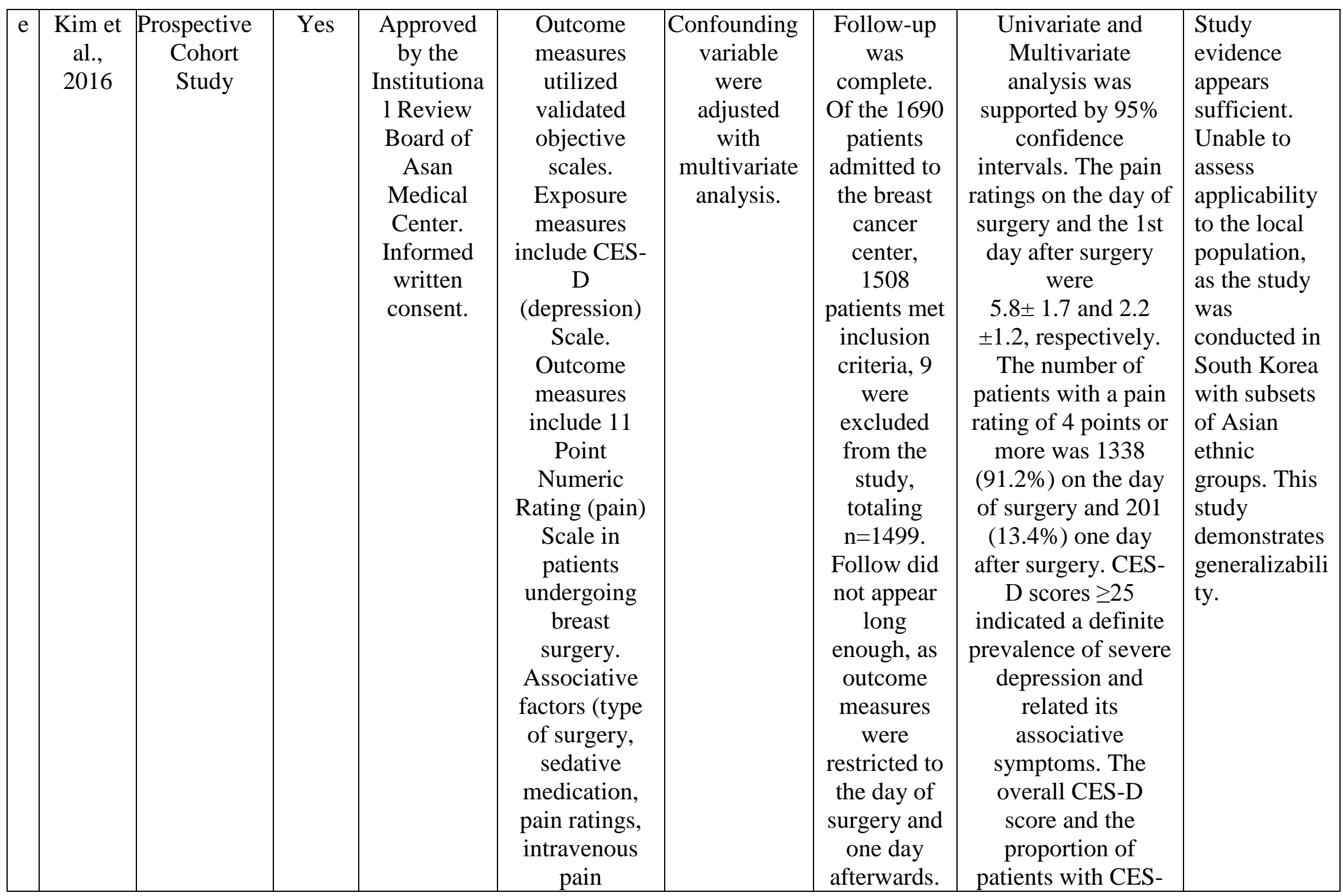




\begin{tabular}{|l|l|l|c|l|l|}
\hline & & & $\begin{array}{c}\text { medications } \\
\text { influenced the } \\
\text { exposure and } \\
\text { outcome } \\
\text { measures. }\end{array}$ & & $\begin{array}{c}\text { D scores of } \geq 25 \\
\text { were } 18.5 \pm 9.7, \text { or } \\
24.1 \%(362 / 1499), \\
\text { respectively. Pain } \\
\text { ratings of } \geq 4 \text { on } \\
\text { both the day of } \\
\text { surgery and one day } \\
\text { afterwards were } \\
\text { positively } \\
\text { associated with } \\
\text { preoperative CES-D } \\
\text { scores of } \geq 25 .\end{array}$ \\
\end{tabular}




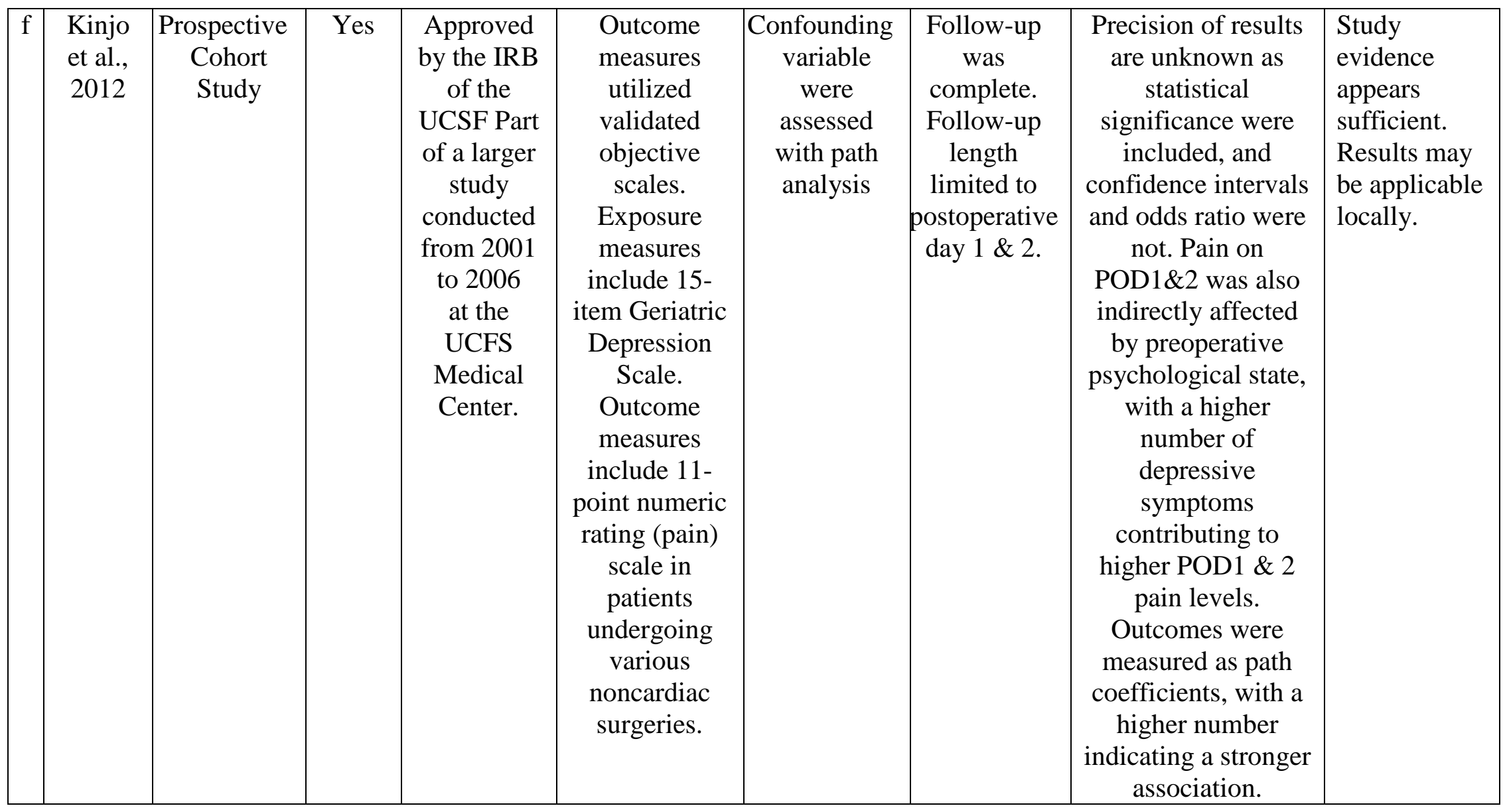




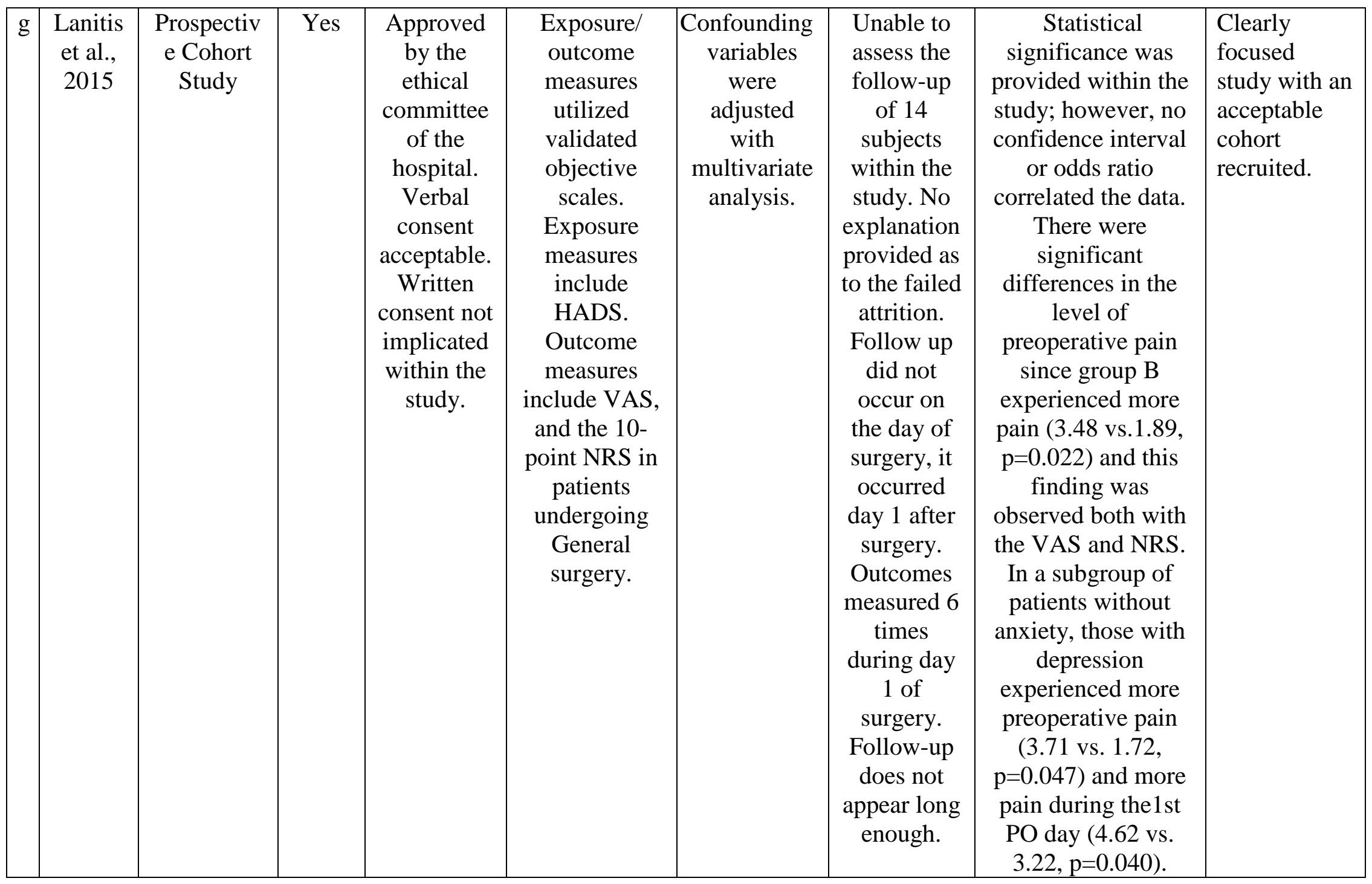




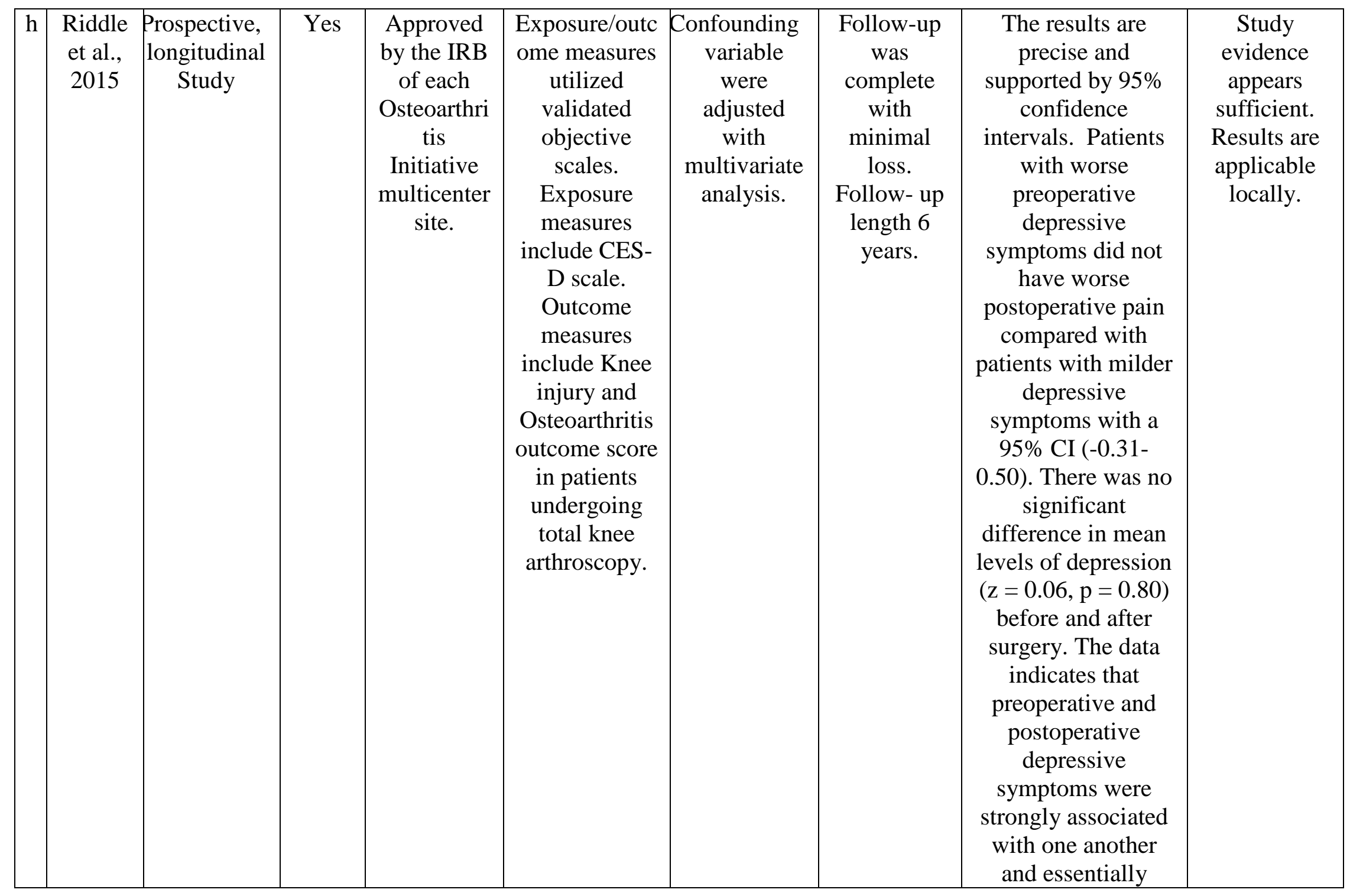




\begin{tabular}{|l|l|l|l|l|l|l|l|}
\hline & & & & & & & unchanged after \\
surgery.
\end{tabular}




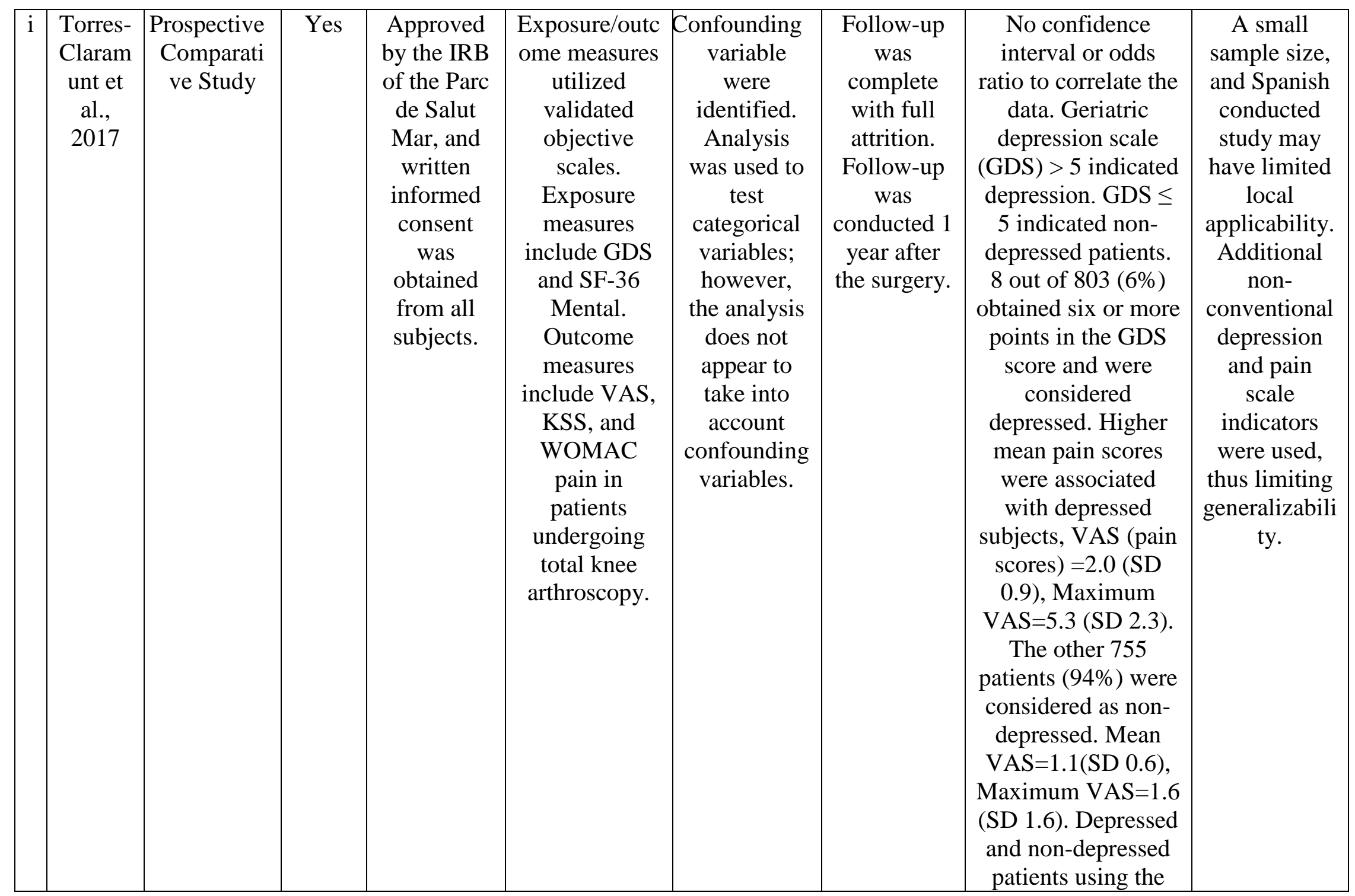




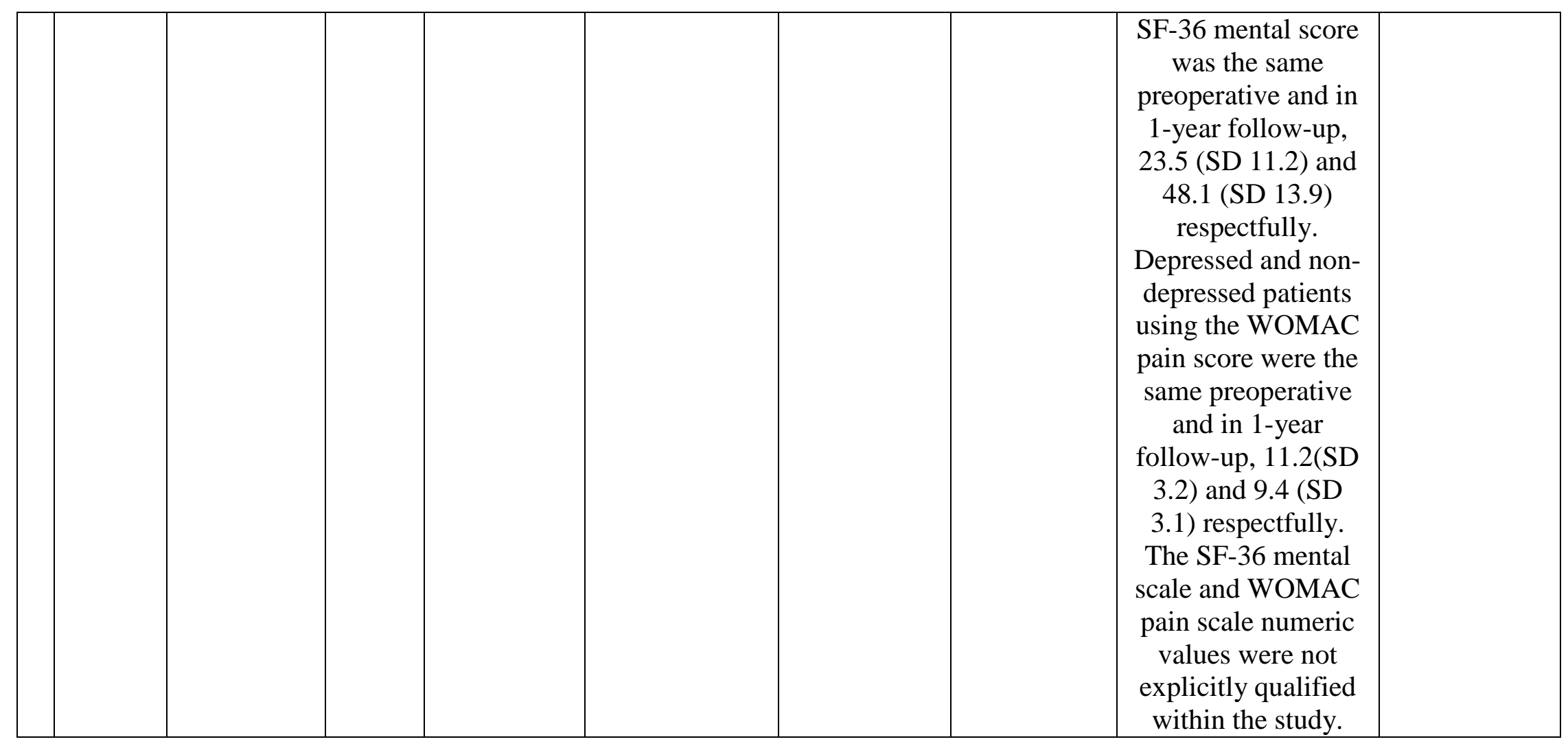




\section{Appendix E}

Data Collection: Cross Study Analysis

\begin{tabular}{|c|c|c|c|c|c|}
\hline & $\begin{array}{l}\text { Author, Year, Type } \\
\text { of Procedure }\end{array}$ & $\begin{array}{c}\text { Depression } \\
\text { Scale/ Exposure } \\
\text { Measures }\end{array}$ & $\begin{array}{l}\text { Pain Scale/ } \\
\text { Outcome } \\
\text { Measures }\end{array}$ & $\begin{array}{c}\text { Anesthetic Technique/ Pain } \\
\text { Management }\end{array}$ & $\begin{array}{l}\text { Post-operative Pain } \\
\text { Results/Follow-up }\end{array}$ \\
\hline 1 & $\begin{array}{l}\text { Caumo et al., } 2002 \\
\text { Abdominal Surgery }\end{array}$ & $\begin{array}{c}\text { The } \\
\text { Montgomery- } \\
\text { Asberg } \\
\text { Depression } \\
\text { Rating Scale } \\
\\
\text { The highest } \\
\text { quartile cutoff } \\
\text { point for } \\
\text { classification of } \\
\text { depressive } \\
\text { symptoms } \\
\text { (Q75=13). } \\
\text { Moderate to } \\
\text { intense } \\
\text { depressive } \\
\text { symptoms } \\
\text { (>13), Mild } \\
\text { depressive } \\
\text { symptoms ( } \leq \\
13) .\end{array}$ & $\begin{array}{c}\text { 100-mm } \\
\text { Visual Analog } \\
\text { Scale (VAS) } \\
\text { VAS scores } \\
\text { ranged from 0 } \\
\text { (no pain) to } 11 \\
\text { (worst } \\
\text { possible pain) } \\
\\
\text { 30-mm cutoff } \\
\text { point for } \\
\text { classification } \\
\text { of pain } \\
\text { symptoms. } \\
\text { Absent to no } \\
\text { pain } \leq 30 \mathrm{~mm} \text {. } \\
\text { Moderate, } \\
\text { intense, or } \\
\text { worst possible } \\
\text { pain }>30 \mathrm{~mm} \text {. }\end{array}$ & $\begin{array}{l}\text { Neural Block (subarachnoid } \\
\text { or epidural, Bupivacaine or } \\
\text { Ropivacaine) without or in } \\
\text { combination with general } \\
\text { anesthesia (isoflurane, } \\
\text { oxygen, with or without } \\
\text { nitrous oxide, thiopental, } \\
\text { propofol, midazolam, } \\
\text { fentanyl, and neuromuscular } \\
\text { blockade). } \\
\text { Effectiveness of } \\
\text { intraoperative fentanyl was } \\
\text { established by using the } \\
\text { highest quartile cutoff } \\
\text { 7.14 } \mathrm{mcg} / \mathrm{kg}^{-1} \text {, the cutoff } \\
\text { point using the highest } \\
\text { quartile for midazolam was } \\
0.10 \mathrm{mcg}^{-1} \mathrm{~kg}^{-1}\end{array}$ & $\begin{array}{l}\text { Pain outcomes were } \\
\text { measured 12-24 hrs. } \\
\text { postoperative. } \\
\text { Precise results with 95\% } \\
\text { CI (1.36-2.15). } \\
\text { The mean (+/-SD) of } \\
\text { depression symptoms } \\
\text { were } 8.32+/-8.17 . \\
\text { Absence or mild pain } \\
\text { (n=196), and moderate } \\
\text { to intense pain (n=150). } \\
\text { Among subjects with } \\
\text { mild to moderate/intense } \\
\text { depression, } 29 \text { of } 167 \\
\text { subjects endorsed to } \\
\text { absent or mild pain, and } \\
51 \text { of } 99 \text { subjects } \\
\text { endorsed to moderate to } \\
\text { intense pain. }\end{array}$ \\
\hline
\end{tabular}




\begin{tabular}{|c|c|c|c|c|c|}
\hline 2 & $\begin{array}{l}\text { Chaichana et al., } \\
\qquad 2011 \\
\text { Lumbar Surgery }\end{array}$ & $\begin{array}{c}\text { Zung Self- } \\
\text { Rating } \\
\text { Depression } \\
\text { 1-100- point } \\
\text { scale with } \\
\text { higher scores } \\
\text { indicating more } \\
\text { severe } \\
\text { depression. } \\
\text { Lower Zung } \\
\text { quartile score } \\
\text { (least } \\
\text { depressed). } \\
\text { Highest Zung } \\
\text { quartile score } \\
\text { (most } \\
\text { depressed) } \\
\\
\text { Modified } \\
\text { Somatic } \\
\text { Perception } \\
\text { Questionnaire 0- } \\
\text { to 39-point scale } \\
\text { with greater } \\
\text { scores } \\
\text { indicating more } \\
\text { severe somatic } \\
\text { symptoms. } \\
\text { Lower MSPQ, } \\
\text { least somatized, }\end{array}$ & $\begin{array}{l}\text { Visual Analog } \\
\text { Scale (VAS). } \\
\text { Back pain } \\
\text { (BP) and leg } \\
\text { pain (LP) } \\
\text { were } \\
\text { measured } \\
\text { separately. } \\
\text { VAS-BP and } \\
\text { VAS-LP } \\
\text { respectively. } \\
\\
0-10 \text { Scale. } \\
0=\text { no pain, } \\
\text { and } 10=\text { most } \\
\text { severe pain. }\end{array}$ & $\begin{array}{l}\text { No reported anesthetic } \\
\text { technique/ pain management }\end{array}$ & $\begin{array}{l}\text { Pain outcomes were } \\
\text { measured preoperatively, } \\
\text { at } 6 \text { weeks, and at } 3,6 \text {, } \\
\text { 9, and } 12 \text { months } \\
\text { postoperatively. } \\
\text { Preoperatively mean } \\
\text { scores: VAS-BP, } 6.1 \pm \\
\text { 5.6; VAS-LP, } 6.1 \pm 5.6 \text {. } \\
\text { Patients reported a } \\
\text { baseline mean Zung } \\
\text { Scale score of } 18.5 \pm \\
\text { 10.6 and a baseline mean } \\
\text { MSPQ score of } 8.9 \pm \\
7.1 . \\
\text { 6 weeks to } 12 \text { months } \\
\text { postoperative mean } \\
\text { scores: } 3.8 \pm 3.3 \text { points } \\
\text { for VAS-BP, } 3.2 \pm 3.5 \\
\text { points for VAS-LP } \\
\text { Patients in the lowest } \\
\text { Zung score quartile } \\
\text { experienced significantly } \\
\text { greater mean } \\
\text { improvement in VAS-LP } \\
\text { score (5.3 } \pm 2.4 \text { vs } 3.8 \pm \\
\text { 3.4, p }=0.08 \text { ). When } \\
\text { evaluating BP and LP }\end{array}$ \\
\hline
\end{tabular}




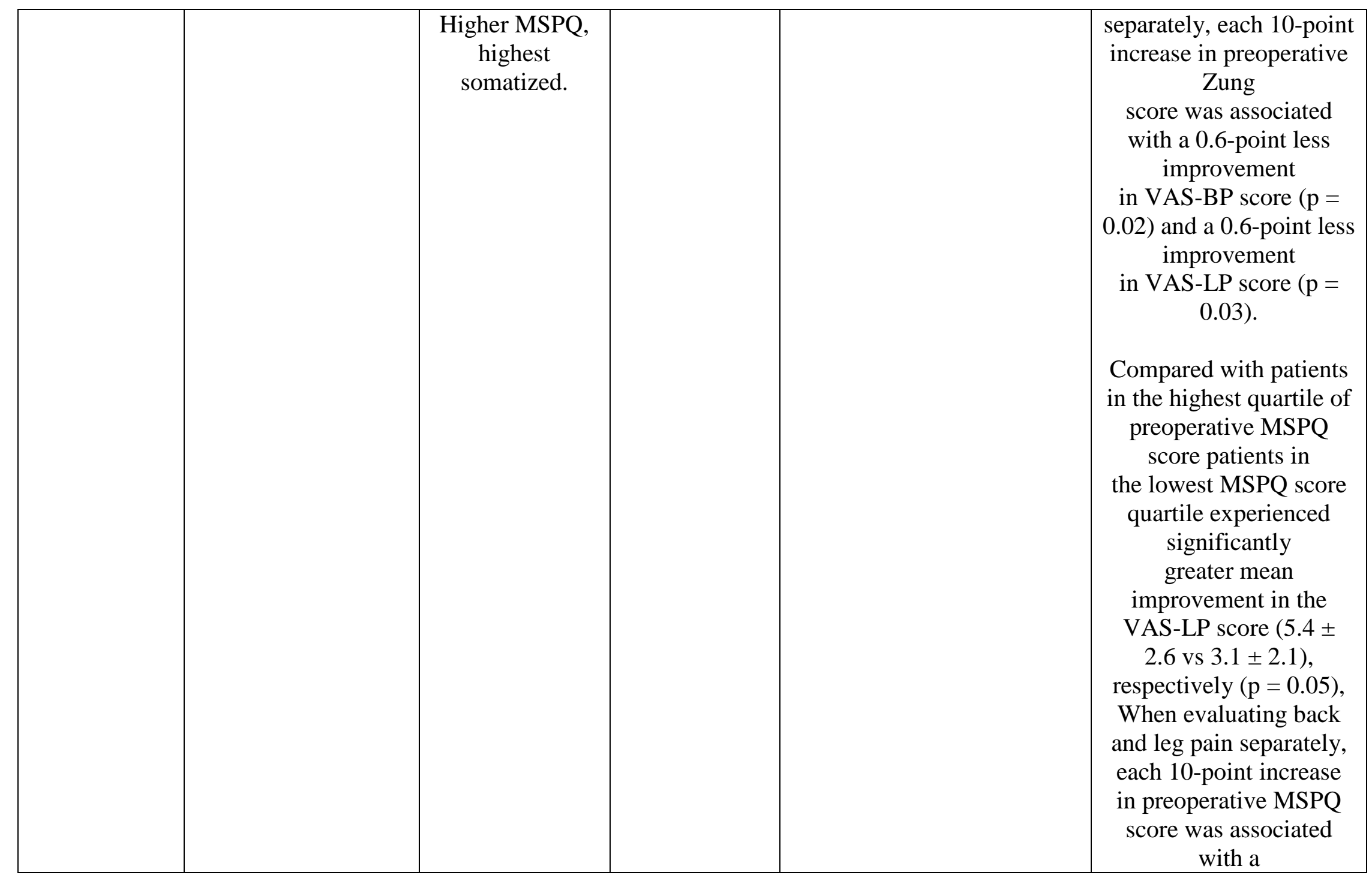




\begin{tabular}{|c|c|c|c|c|c|}
\hline & & & & & $\begin{array}{c}\text { 1.0-point less } \\
\text { improvement in VAS- } \\
\text { BP score }(\mathrm{p}=0.005) \\
\text { and a 1.4-point less } \\
\text { improvement in VAS-LP } \\
\text { score }(\mathrm{p}< \\
0.001) .\end{array}$ \\
\hline 3 & $\begin{array}{l}\text { Cohen et al., } 2005 \\
\text { Abdominal } \\
\text { Gynecologic } \\
\text { Surgery }\end{array}$ & $\begin{array}{l}\text { The Mental } \\
\text { Health } \\
\text { Inventory } \\
\text { (MHI) } \\
\text { Impact of event } \\
\text { scale (IES) and } \\
\text { Negative Affect } \\
\text { (NA) were } \\
\text { measured as } \\
\text { preoperative } \\
\text { psychosocial } \\
\text { measures } \\
\text { correlative to } \\
\text { MHI. } \\
\text { 18-item scale } \\
\text { with scores } \\
\text { ranging from 0- } \\
\text { 108. Higher } \\
\text { scores were } \\
\text { indicative of } \\
\text { improved } \\
\text { mental health. }\end{array}$ & $\begin{array}{l}\text { The McGill } \\
\text { Pain } \\
\text { Questionnaire } \\
\text { Yields two } \\
\text { global scores, } \\
\text { the pain rating } \\
\text { index (PRI-T) } \\
\text { and the } \\
\text { present pain } \\
\text { intensity } \\
\text { (PPI). The } \\
\text { PRI-T was } \\
\text { only reported } \\
\text { for analysis. } \\
\text { Morphine } \\
\text { consumption } \\
\text { measured } 24 \\
\text { and } 48 \text { hours } \\
\text { post operation }\end{array}$ & $\begin{array}{l}\text { Intravenous patient- } \\
\text { controlled analgesic (PCA) } \\
\text { pump containing morphine. } \\
\text { 1.0-1.5-mg intravenous } \\
\text { bolus doses with lock out } \\
\text { time of } 5 \text { minutes. } 40 \mathrm{mg} \\
\text { maximum dose in } 4 \text { hours. } \\
\text { Pre-incisional, post- } \\
\text { incisional, and sham } \\
\text { incisional epidurals used for } \\
\text { pain management. }\end{array}$ & $\begin{array}{c}\text { Pain outcomes were } \\
\text { measured } 48 \text { hours post } \\
\text { operation with 4-week } \\
\text { follow-up. } \\
\text { Morphine consumption } \\
\text { after surgery ( } \mathrm{P}=.027) \\
\text { and self-distraction } \\
\text { coping ( } \mathrm{P}=.039) \text { were } \\
\text { independently positively } \\
\text { associated with } 48 \text {-h } \\
\text { PRI-T scores, concurrent } \\
\text { NA ( } \mathrm{P}=.055) \text {, } \\
\text { preoperative NA } \\
\text { ( } \mathrm{P}=.078) \text {, and } \\
\text { preoperative IES scores } \\
(\mathrm{P}=.10) \text { were marginally } \\
\text { associated with PRI-T } \\
\text { scores } 48 \text { h after surgery. } \\
\text { Preoperative IES scores } \\
\text { (P=.008), preoperative } \\
\text { NA ( } \mathrm{P}=.041) \text {, use of } \\
\text { emotional support } \\
\text { coping ( } \mathrm{P}=.049 \text { ), }\end{array}$ \\
\hline
\end{tabular}




\begin{tabular}{|c|c|c|c|c|c|}
\hline & & & & & $\begin{array}{c}\text { religious-based coping } \\
(\mathrm{P}=.001) \text {, behavioral } \\
\text { disengagement coping } \\
(\mathrm{P}=.034) \text {, and concurrent } \\
\mathrm{NA}(\mathrm{P}=.009) \text { were all } \\
\text { independently positively } \\
\text { associated with PRI-T } \\
\text { scores } 4 \text { weeks after } \\
\text { surgery. }\end{array}$ \\
\hline 4 & $\begin{array}{l}\text { Dadgostar et al., } \\
2017 \\
\text { Multiple/Various } \\
\text { Surgeries/Procedures }\end{array}$ & $\begin{array}{c}\text { Hamilton } \\
\text { Depression } \\
\text { Scale, Beck } \\
\text { Depression } \\
\text { Index, Self- } \\
\text { Rating } \\
\text { Questionnaire } \\
\text { for Depression, } \\
\text { Hospital anxiety } \\
\text { and Depression } \\
\text { scale, 15-item } \\
\text { Geriatric } \\
\text { Depression } \\
\text { Scale, Major } \\
\text { Depressive } \\
\text { Disorder Scale, } \\
\text { German Center } \\
\text { of } \\
\text { Epidemiological }\end{array}$ & $\begin{array}{l}\text { Visual Analog } \\
\text { Scale, Brief } \\
\text { Pain } \\
\text { Inventory, } \\
\text { Semmes- } \\
\text { Weinstein } \\
\text { Mechanical } \\
\text { Esthesiometer, } \\
\text { Verbal Rating } \\
\text { Scale, 11- } \\
\text { Point Numeric } \\
\text { Scale, 10- } \\
\text { point Numeric } \\
\text { Rating Scale, } \\
\text { Verbal } \\
\text { Numeric } \\
\text { Rating Scale, } \\
\text { Numerical } \\
\text { Rating Scale, }\end{array}$ & $\begin{array}{l}\text { Postoperative PCA requests } \\
\text { Morphine administration } \\
\text { Multimodal Analgesia }\end{array}$ & $\begin{array}{c}8 \text { out of } 18 \text { studies } \\
\text { reported a positive effect } \\
\text { of depression on } \\
\text { postoperative pain scores } \\
\text { totaling } 1314 \text { patients. } \\
\text { Procedure types } \\
\text { demonstrating these } \\
\text { positive effects included: } \\
\text { gastric bypass, } \\
\text { laparoscopic } \\
\text { cholecystectomy, radical } \\
\text { prostatectomy, } \\
\text { arthroplasty, dental } \\
\text { implant on mandibular } \\
\text { pain, total hip } \\
\text { replacement and } \\
\text { fixation, and middle } \\
\text { ear/laryngopharyngeal } \\
\text { surgery. } 10 \text { of } 18 \text { studies }\end{array}$ \\
\hline
\end{tabular}




\begin{tabular}{|c|c|c|c|c|c|}
\hline & & $\begin{array}{c}\text { Studies } \\
\text { Depression } \\
\text { Scale, Patient } \\
\text { Health } \\
\text { Questionnaire } \\
\text { Exposure } \\
\text { related data } \\
\text { includes: } \\
\text { depression } \\
\text { diagnosis, } \\
\text { assessment, } \\
\text { questionnaire, } \\
\text { treated } \\
\text { depression, and } \\
\text { co-existing } \\
\text { mental health }\end{array}$ & $\begin{array}{c}\text { Quality } \\
\text { Improvement } \\
\text { in } \\
\text { Postoperative } \\
\text { Pain } \\
\text { Management } \\
\text { Scale } \\
\text { Outcome } \\
\text { related data } \\
\text { includes: pain } \\
\text { assessments, } \\
\text { pain scales } \\
\text { used, average } \\
\text { score on pain } \\
\text { scale, types of } \\
\text { medication } \\
\text { usage, exact } \\
\text { medication } \\
\text { name, } \\
\text { medication } \\
\text { dosage, } \\
\text { medication } \\
\text { frequency, } \\
\text { medication } \\
\text { frequency } \\
\text { (other). }\end{array}$ & & $\begin{array}{c}\text { reported a negative } \\
\text { effect of depression on } \\
\text { postoperative pain scores } \\
\text { totaling } 1226 \text { patients. } \\
\text { Procedure types } \\
\text { demonstrating these } \\
\text { negative effects include: } \\
\text { mastectomy/lumpectomy } \\
\text { with lymph node } \\
\text { dissection, dental } \\
\text { implant on maxillary } \\
\text { pain, various ENT } \\
\text { procedures, cardiac } \\
\text { surgery, total knee } \\
\text { arthroscopy, elective } \\
\text { cardiac surgery, and } \\
\text { laparoscopic } \\
\text { hysterectomy. }\end{array}$ \\
\hline 5 & $\begin{array}{c}\text { Kim et al., } 2016 \\
\text { Breast and Axillary } \\
\text { Surgery }\end{array}$ & $\begin{array}{c}\text { Center of } \\
\text { Epidemiological } \\
\text { Studies }\end{array}$ & $\begin{array}{c}\text { 11- Point } \\
\text { Numeric } \\
\text { Rating Scale } \\
\text { (NRS) }\end{array}$ & $\begin{array}{c}\text { Zolpidem provided the night } \\
\text { before surgery per patient } \\
\text { request }\end{array}$ & $\begin{array}{l}\text { Pain outcome measures } \\
\text { obtained at } 1 \text { hour after } \\
\text { operation, and on }\end{array}$ \\
\hline
\end{tabular}




\begin{tabular}{|c|c|c|c|c|c|}
\hline & & $\begin{array}{c}\text { Depression } \\
\text { Scale (CES-D) } \\
\\
\text { CES-D range } \\
(0-57) \text {. } \\
\text { CES-D cutoff } \\
\text { scores } \geq 25 \\
\text { corresponded } \\
\text { with severe } \\
\text { depressive } \\
\text { symptoms/major } \\
\text { depression }\end{array}$ & $\begin{array}{l}\text { NRS cutoff } \\
\text { score of } 4 \text {. No } \\
\text { pain to mild } \\
\text { pain }(0-3), \\
\text { moderate pain } \\
\text { or severe pain } \\
(4-10)\end{array}$ & $\begin{array}{c}\text { Intravenous ketorolac for } \\
\text { postoperative pain per } \\
\text { patient request. }\end{array}$ & $\begin{array}{c}\text { postoperative day } 1 \text { at } \\
0800 \text {. } \\
\text { CES-D Scores } \geq 25 \text { had } \\
\text { a mean of } 18.5 \pm 9.7 \text { and } \\
24.1 \% \text { respectively. } \\
\text { Postoperative pain } \\
\text { ratings on the day of } \\
\text { surgery and } 1 \text { day } \\
\text { following surgery had a } \\
\text { mean of } 5.8 \pm 1.7 \text { and } \\
2.2 \pm 1.2 \text {. } \\
\text { Patients with pain } \\
\text { ratings } \geq 4 \text { were } 91.2 \% \\
\text { the patient population } \\
\text { (n=1499), and on the day } \\
\text { after surgery was } 13.4 \% \\
\text { of the patient population }\end{array}$ \\
\hline 6 & $\begin{array}{c}\text { Kinjo et al., } 2012 \\
\text { Multiple/Various } \\
\text { Surgeries/Procedures }\end{array}$ & $\begin{array}{l}\text { 15-item } \\
\text { Geriatric } \\
\text { Depression } \\
\text { Scale (15) } \\
\text { GDS cutoff } \\
\text { score for } \\
\text { classification } \\
=6,<6 \\
\text { correlating to a } \\
\text { lesser degree of }\end{array}$ & $\begin{array}{l}\text { 11- Point } \\
\text { Numeric } \\
\text { Rating Scale } \\
\text { (NRS) } \\
\text { 0-11 Scale. } \\
0=\text { no pain, } \\
\text { and } 11=\text { worst } \\
\text { possible pain. }\end{array}$ & $\begin{array}{c}\text { Intravenous patient- } \\
\text { controlled analgesic (IV- } \\
\text { PCA) pump containing } \\
\text { hydromorphone, morphine, } \\
\text { or fentanyl. } \\
\text { 0.2- mg intravenous bolus } \\
\text { doses with lock out time of } \\
6 \text { minutes. For patient } \\
\text { allergy or hypersensitivity, } \\
\text { morphine ( } 5 \text { mg morphine }\end{array}$ & $\begin{array}{c}\text { Pain outcomes measured } \\
\text { at rest preoperatively, } \\
\text { and postoperatively on } \\
\text { postoperative day (POD) } \\
1 \text { and POD } 2 . \\
\text { Greater preoperative } \\
\text { GDS scores were } \\
\text { associated with greater } \\
\text { pain }(0.110 ;<0.05) .\end{array}$ \\
\hline
\end{tabular}




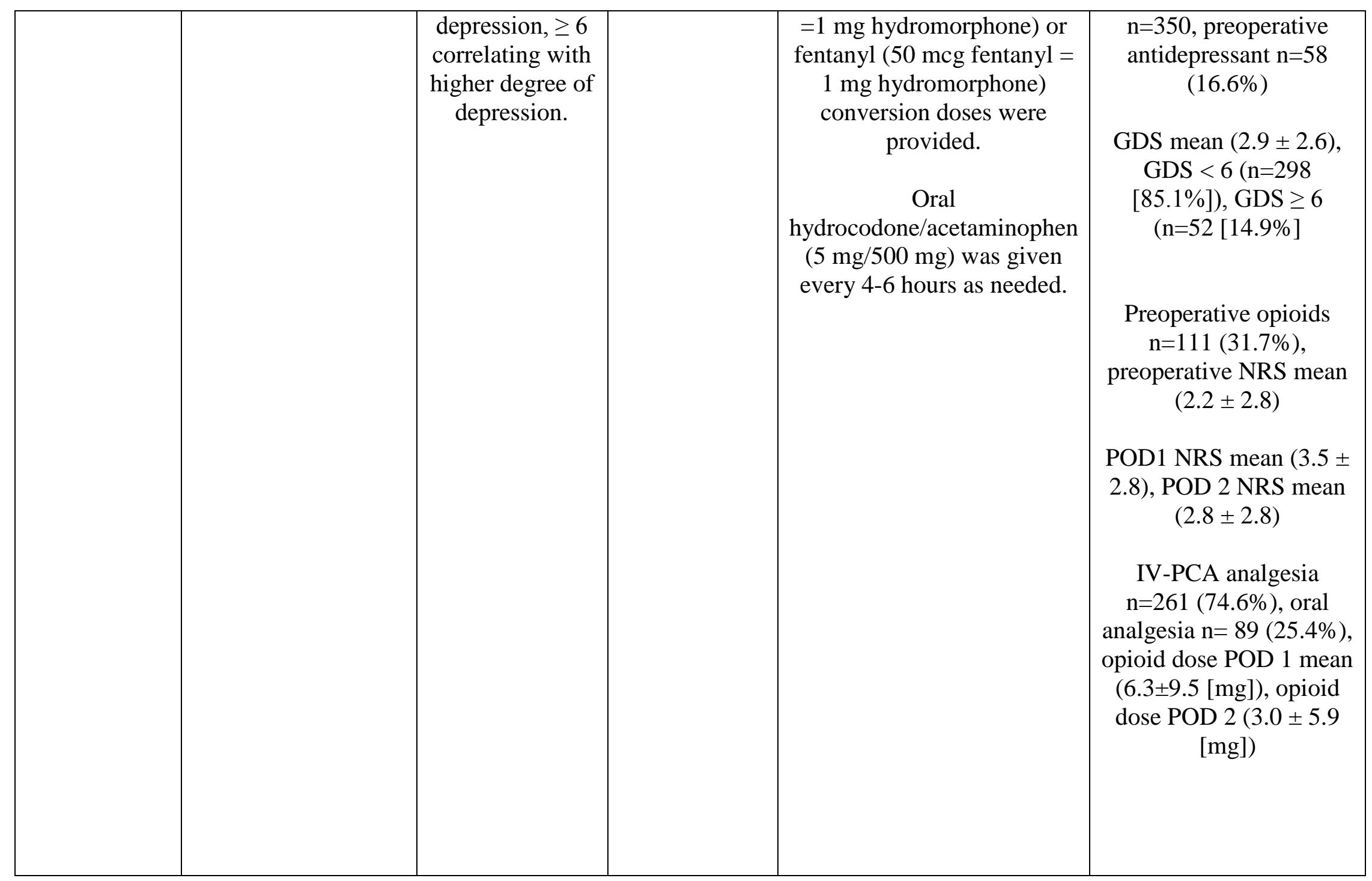




\begin{tabular}{|c|c|c|c|c|c|}
\hline 7 & $\begin{array}{c}\text { Lanitis et al., } 2015 \\
\text { General Surgery }\end{array}$ & $\begin{array}{c}\text { Hospital } \\
\text { Anxiety and } \\
\text { Depression } \\
\text { Scale (HADS) } \\
\text { HADS score } \\
\text { ranging from 0- } \\
\text { 21. Patients } \\
\text { classified in two } \\
\text { groups with } \\
\text { cutoff score of } \\
\text { 7. Group A = } \\
\text { normal (0-7), } \\
\text { Group B= level } \\
\text { of depression } \\
(>7) \text {. }\end{array}$ & $\begin{array}{l}\text { Visual Analog } \\
\text { Scale (VAS) } \\
\text { Identification } \\
\text { of pain on a } \\
\text { continuous } \\
\text { line between } \\
\text { two end points } \\
\text { ranging from } \\
\text { no pain to } \\
\text { maximum } \\
\text { pain } \\
\\
\text { 10-point } \\
\text { Numeric } \\
\text { Rating Scale } \\
\text { (NRS) } \\
\text { Segmented } \\
\text { numeric } \\
\text { version of } \\
\text { VAS, where } \\
0=\text { no pain, } \\
\text { 10= maximum } \\
\text { pain }\end{array}$ & $\begin{array}{c}\text { NSAIDS } \\
(1-2 / 24 \text { hours }) \\
\text { Strong pain killers } \\
\text { Tramadol HCL 50mg } \\
\text { /pethidine } 50 \mathrm{mg}(1-2 / 24 \\
\text { hours) or Tramadol HCL } \\
\text { 50mg /pethidine 50 mg } \\
\text { (>3/24 hours) }\end{array}$ & $\begin{array}{l}\text { Pain outcomes measured } \\
\text { at day } 1 \text { after surgery. } \\
\text { n= 400, Group A (no } \\
\text { depression) }=80.75 \%, \\
\text { Group B (some level of } \\
\text { depression) }=15.75 \% \\
\text { Group A preoperative } \\
\text { NRS }=1.86(2.95), 1^{\text {st }} \\
\text { Postoperative }(\text { PO) } \\
\text { NRS }=3.31(2.64), 2^{\text {nd }} \\
\text { PO NRS }=2.30(2.43), 3^{\text {rd }} \\
\text { PO NRS }=1.58(2.15), 4^{\text {th }} \\
\text { PO NRS }=1.08(1.8), 5^{\text {th }} \\
\text { PO NRS }=0.77(1.59), 6^{\text {th }} \\
\text { PO NRS }=0.57(1.42) \\
\text { Group A preoperative } \\
\text { VAS }=1.99(3.06), 1^{\text {st }} \text { PO } \\
\text { VAS }=3.29(2.71), 2^{\text {nd }} \\
\text { PO VAS }=2.30(2.46), 3^{\text {rd }} \\
\text { PO VAS }=1.54(2.11), 4^{\text {th }} \\
\text { PO VAS }=1.09(1.82), 5^{\text {th }} \\
\text { PO VAS }=0.73(1.59), 6^{\text {th }} \\
\text { PO VAS }=0.57(1.41) \\
\text { Group B preoperative } \\
\text { NRS }=3.22(3.89), 1^{\text {st }} P O \\
\text { NRS }=4.43(3.03), 2^{\text {nd }} \\
\text { PO NRS }=2.94(2.65), 3^{\text {rd }}\end{array}$ \\
\hline
\end{tabular}




\begin{tabular}{|c|c|c|c|c|c|}
\hline & & & & & $\begin{array}{c}\text { PO NRS }=2.08(2.28), 4^{\text {th }} \\
\text { PO NRS }=1.35(1.91), 5^{\text {th }} \\
\text { PO NRS }=0.98(1.67), 6^{\text {th }} \\
\text { PO NRS }=0.83(1.64) \\
\text { Group B preoperative } \\
\text { VAS }=3.40(3.64), 1^{\text {st }} \text { PO } \\
\text { VAS }=4.40(3.08), 2^{\text {nd }} \\
\text { PO VAS }=2.94(2.62), 3^{\text {rd }} \\
\text { PO VAS }=1.98(2.25), 4^{\text {th }} \\
\text { PO VAS }=1.30(1.89), 5^{\text {th }} \\
0.98(1.68), 6^{\text {th }} \text { PO VAS= } \\
0.97(1.63) \\
\text { Use of narcotics in } \\
\text { Group A }=88.6 \%, \text { Group } \\
\text { B 63.5\%. Use of } \\
\text { analgesics in Group A }= \\
\text { 83.1\%, Group B= 68.3\% }\end{array}$ \\
\hline 8 & $\begin{array}{c}\text { Riddle et al., } 2015 \\
\text { Total Knee } \\
\text { Arthroscopy }\end{array}$ & $\begin{array}{c}\text { Center of } \\
\text { Epidemiological } \\
\text { Studies } \\
\text { Depression } \\
\text { Scale (CES-D) } \\
\\
\text { CES-D range } \\
\text { (0- 60). CES-D } \\
\text { cutoff scores } \geq \\
16 \text { indicating }\end{array}$ & $\begin{array}{c}\text { Knee Injury } \\
\text { and } \\
\text { Osteoarthritis } \\
\text { Outcome } \\
\text { Score (KOOS) } \\
\\
\text { Pain scale } \\
\text { range from 0 } \\
\text { (severe } \\
\text { function } \\
\text { limiting pain) }\end{array}$ & $\begin{array}{c}\text { No reported anesthetic } \\
\text { technique/ pain management }\end{array}$ & $\begin{array}{l}\text { Pain outcomes were } \\
\text { measured over a 7-year } \\
\text { period, } 3 \text { years before } \\
\text { surgery, and } 3 \text { years } \\
\text { after surgery. } \\
\\
\text { Preoperative CES-D } \\
\text { Scores } \geq 16=11.8 \% \text {. } \\
\text { Mean depressive } \\
\text { symptoms= } 7.3( \pm 6.9) \text {. }\end{array}$ \\
\hline
\end{tabular}




\begin{tabular}{|c|c|c|c|c|c|}
\hline & & $\begin{array}{c}\text { probable clinical } \\
\text { depression. }\end{array}$ & $\begin{array}{l}\text { to } 100 \text { (no } \\
\text { pain with } \\
\text { function) }\end{array}$ & & $\begin{array}{c}\text { Mean CES-D=6.81 } \\
\text { (Standard Error } \\
[\mathrm{SE}]=0.42) \\
\text { Mean depressive } \\
\text { variance 30.13 } \\
(\mathrm{SE}=4.14) \\
\\
\text { Preoperative mean } \\
\text { KOOS=65.85 } \\
\text { (SE=1.15), mean } \\
\text { variance }=187.59 \\
(\mathrm{SE}=22.60) . \\
\\
\text { Postoperative CES-D } \\
\text { mean= 6.74(SE=0.41), } \\
\text { mean variance } \\
=23.96(\mathrm{SE}=3.52) \\
\\
\text { Postoperative KOOS } \\
\text { mean= 84.84(SE=1.10), } \\
\text { mean variance }= \\
\text { 159.08(SE=24.87) }\end{array}$ \\
\hline 9 & $\begin{array}{c}\text { Torres-Claramunt et } \\
\text { al., } 2017 \\
\text { Total Knee } \\
\text { Arthroplasty }\end{array}$ & $\begin{array}{c}\text { Geriatric } \\
\text { Depression } \\
\text { Scale Short } \\
\text { Form (GDS) }\end{array}$ & $\begin{array}{l}\text { 100mm Visual } \\
\text { Analog Scale } \\
\text { (VAS) }\end{array}$ & $\begin{array}{l}\text { Intraoperative intradural } \\
\text { anesthesia ( } 15 \mathrm{mg} \\
\text { levobupivacaine } 0.5 \%) \text { with } \\
\text { tourniquet pressure. }\end{array}$ & $\begin{array}{l}\text { Pain outcome were } \\
\text { measured post-operation, } \\
\text { every } 8 \text { hours, for the } \\
\text { first } 72 \text { hours. }\end{array}$ \\
\hline
\end{tabular}




\begin{tabular}{|c|c|c|c|c|c|}
\hline & & $\begin{array}{l}\text { GDS cutoff } \\
\text { score for } \\
\text { classification } \\
=5, \leq 5 \text { were } \\
\text { classified as } \\
\text { clinically non- } \\
\text { depressed, > } 6 \\
\text { were clinically } \\
\text { depressed. }\end{array}$ & $\begin{array}{l}\text { VAS scores } \\
\text { ranged from } 0 \\
\text { (absence of } \\
\text { pain) to } \\
\text { 100mm (worst } \\
\text { possible pain). } \\
\text { Score ranges } \\
\text { from 0-10 } \\
\text { were } \\
\text { substitutive } \\
\text { within the } \\
\text { results. }\end{array}$ & $\begin{array}{c}\text { Postoperative ultrasound } \\
\text { guided single-shot femoral } \\
\text { and sciatic nerve block with } \\
0.2 \% \text { levobupivacaine } 25 \mathrm{ml} \text {. } \\
\text { Postoperative intravenous } \\
\text { analgesic protocol } \\
\text { (Paracetamol 1g/6 hours and } \\
\text { Dexketoprofen 50mg/12 } \\
\text { hours for the first } 48 \text { hours. } \\
\text { Postoperative oral analgesic } \\
\text { protocol (paracetamol } 1 \mathrm{~g} / 6 \\
\text { hours and Ibuprofen } 600 \mathrm{mg} / \\
\text { hours). } \\
\text { Rescue analgesia (1mg/kg/h } \\
\text { of morphine divided into } 4 \\
\text { doses). }\end{array}$ & $\begin{array}{c}\mathrm{n}=803, \mathrm{GDS}>6= \\
48(6 \%), \mathrm{GDS}<6= \\
755(94 \%) \\
\\
\text { Depressed (n=48) mean } \\
\mathrm{VAS}=2.0(\mathrm{Standard} \\
\text { deviation [SD]=0.9), } \\
\text { maximum VAS=5.3 } \\
\text { (SD=2.3), number of } \\
\text { rescues= 4.4(SD=2.6). } \\
\\
\text { Non-Depressed }(\mathrm{n}=755) \\
\text { mean VAS=1.1 } \\
\text { (SD=0.6), maximum } \\
\mathrm{VAS}=1.6(\mathrm{SD}=1.6), \\
\text { number of } \\
\text { rescues=1.8(SD=1.9). }\end{array}$ \\
\hline
\end{tabular}


